\title{
O RELEVO BRASILEIRO NO CONTEXTO DA AMÉRICA DO SUL
}

\author{
Jurandyr Luciano Sanches Ross
}

Universidade de São Paulo

\begin{abstract}
Resumo
O relevo brasileiro só pode ser entendido a partir dos processos geomorfológicos que afetaram o continente sul-americano. Os processos morfogenéticos do Brasil estão relacionados com a abertura do Oceano Atlântico e a formação da Cadeia Orogenética dos Andes. A epirogênese meso-cenozóica desencadeou os processos desnudacionais e estabeleceram a compartimentação do relevo. As macroformas associam-se às megaestruturas dos Crátons, Cinturões Orogenéticos e Bacias Sedimentares herdadas do Gondwana, produzidas pelas fases erosivas pré e pós-Cretáceo. As variações altimétricas do Planalto Brasileiro decorrem da tectônica que soergueu desigualmente as estruturas que sustentam as macroformas a partir do Cretáceo com vínculos à tectônica Andina. No oeste do continente orogenia e no centro-leste arqueamentos e falhamentos que criaram desníveis de antigas superfícies de erosão, acompanhadas de processos erosivos e deposicionais Terciários e Quaternários, tanto em climas secos como quentes e úmidos que possivelmente geraram rebaixamento geoquímico.
\end{abstract}

Palavras-chave: relevo; processos estruturais; processos esculturais; tectônica; orogênese; epirogênese.

\begin{abstract}
The Brazilian relief can only be understood in the context of what happens in the South American Continent. The morphogenetic processes in Brazil are related to the opening of the Atlantic Ocean and the formation of the Andes orogenic chain. The meso-cenozoic epirogenesis triggered denudacional processes and established the subdivision of relief. The macroforms are associated with the megastrutures of Cratons, Orogenic belts and sedimentary basins inherited from Gondwana, produced by pre and post-Cretaceous erosive phases. The Brazilian Highlands altimetric variations stem from tectonic movements that unevenly uplifted the strutures that support macroforms from the Cretaceous related to the Andean tectonics. The orogeny in the West and the arching and faulting in the Center-east of the continent which created gaps on ancient erosion surfaces, were accompanied by erosive and depositional processes during the Tertiary and Quaternary. Such processes, both in dry and in hot and humid climates possibly generated geochemical relegation.
\end{abstract}

Key words: landforms; structural processes; sculptural processes; tectonics; orogenesis; epirogenesis.

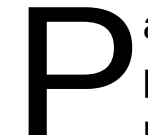
ara ser melhor interpretado, o relevo brasileiro precisa ser contextualizado na macrocompartimentação e geodinâmica do continente sul americano, que por sua vez depende da morfotectônica global. Ficou menos difícil contextualizar a evolução morfogenética das macroformas contidas no território do Brasil e da América do Sul a partir do momento em que pesquisadores da geociência formularam as bases da teoria da Tectônica de Placas. A partir dessa concepção teórica, ainda que possa haver debates sobre sua total validade, criaram-se condições de se interpretar as estruturas geológicas antigas e recentes, bem como os seus efeitos nas formas e na gênese do relevo na perspectiva tectônica e estrutural de modo mais lógico. Os fatos geotectônicos, tanto do passado como do presente, passaram a ser interpretados dentro do arcabouço global do planeta e não mais como fatos regionais ou locais desconectados do todo. 
É evidente que isto também não resolve todas as questões da morfogênese de tempos mais longos que antecedem o Terciário-Quaternário, mas coloca uma luz mais nítida sobre os processos tectônicos recentes e seus correspondentes do passado. Esses processos, bem como os climáticos, se repetem, não como fatos cíclicos distintos, mas como resultantes de dinâmica continua, não uniformes, porém semelhantes. Isso permite que se faça interpretações conjeturais mais audaciosas e possivelmente mais precisas. A teoria geral permite que a litosfera deixe de ser considerada uma camada rígida e pouco mutável, passando a ser concebida como algo sólido, mas que repousa sobre materiais mais plásticos, e ao mesmo tempo constituída por blocos estruturais/litosféricos, individualizados por faixas de tectônica móvel. Nessas faixas, as atividades sísmicas são mais intensas justamente por representarem as áreas de contato e/ou a transição entre um bloco litosférico e outro.

Nesta perspectiva, os blocos estruturais podem ser pensados muito mais como grandes espaços litológicos heterogêneos que repousam sobre o manto, mais denso e mais fluido, como se fossem um "conjunto de barcaças" conectadas entre si, mas com ligeira mobilidade individual acionada pelos mecanismos energéticos endógenos. Estas energias, que emergem do interior do planeta, ao movimentar os materiais do manto externo, mobilizam os mega blocos estruturais que estão na superfície. Nesse contexto, as atividades sísmicas, o vulcanismo, os falhamentos, os dobramentos, as intrusões, os terremotos e os tsunamis são partes de um conjunto de processos geotectônicos que se manifestam constantemente de forma nem sempre perceptível pela sensibilidade humana, devido às suas intensidades variadas. Estes movimentos podem promover alterações mais intensivas, ou seja, rápidas e fortes, mas de curta duração, ou, como é mais regular, alterações lentas, mais constantes, menos perceptíveis e mais duradouras. Assim sendo, a concepção de que os processos geotectônicos são espasmódicos e de comportamento catastrófico é algo superado, ainda que frequentemente os abalos sísmicos, os tsunamis e os vulcanismos provoquem notícias desagradáveis, frente às destruições e mortes que causam. Essas manifestações tectogenéticas são absolutamente esperadas, embora não se possa prevê-las com exatidão, nem no tempo, nem no espaço. Há, entretanto, as faixas territoriais onde há maior probabilidade de ocorrência das atividades tectônicas/sísmicas, conhecidas e genericamente divulgadas, consideradas como áreas de riscos geológicos.

Assim, para se tratar das formas e dos processos responsáveis pela formação do relevo brasileiro, é preciso contextualizá-lo nessa perspectiva da tectônica global, onde os arranjos estruturais de hoje não são os mesmos de tempos geológicos passados, mas se assemelham. A Terra é dinâmica e a litosfera é aparentemente a parte mais sólida e rígida do planeta, estando em constante movimento, ou seja, aquilo que parece ser estável e seguro para os seres vivos, na verdade está em movimento e como tal oferece riscos, em tempos curtos, e sofre mutações, em tempos longos.

As terras emersas da América do Sul, cujos 50\% são brasileiras, fazem parte de algo maior que corresponde à Placa Litosférica sul-americana que envolve também superfícies submersas. De modo simples, pode-se descrever o relevo do continente sul-americano como tendo em sua borda oeste a Cadeia Orogênica dos Andes, cuja formação iniciou-se no Mesozóico e estende-se ao Cenozóico. Acompanha paralelamente a Cordilheira Andina, de norte a sul (desde a Venezuela à Argentina), na porção centro-oeste do continente, uma faixa de terras baixas constituída por planícies e depressões predominantemente esculpidas em sedimentos Cenozóicos recentes. En- 
tretanto, no centro-leste do continente estão as estruturas e formações litológicas antigas que remontam ao Pré-cambriano e que estão parcialmente cobertas por extensas bacias sedimentares fanerozóicas. Nesses terrenos prevalecem as grandes extensões de planaltos e serras entremeados por corredores de depressões periféricas e interplanálticas.

A Cordilheira dos Andes, que é alta, relativamente estreita e alongada, na direção norte-sul, ultrapassa em alguns setores, os $4.000 \mathrm{~m}$ de altitude. Já os terrenos do centro e leste do continente são mais baixos, prevalecendo altitudes inferiores a $1.000 \mathrm{~m}$. Nessa parte, o relevo é mais desgastado por efeito de várias fases erosivas, que geraram simultaneamente as grandes bacias sedimentares e as coberturas descontínuas menos espessas.

O território brasileiro em grande extensão, bem como parte da Venezuela, Suriname e Guianas, estão sobre estruturas geológicas antigas. Ocorrem, entretanto, bacias de sedimentação recente, como as do Pantanal Mato-Grossense, a da Bacia Amazônica Ocidental (Bacia do Solimões), que fazem parte de algo mais extenso que são os sedimentos terciários e quaternários que sustentam o relevo baixo e em grande parte plano do que está aqui se denominando de Depressão Central Sul-americana. Essas formações também estão no litoral leste, nordeste e sul, representadas por coberturas sedimentares terciárias como os tabuleiros costeiros e várias pequenas bacias cenozóicas geradas nas depressões tectônicas (grábens/rifft valleys) incrustradas nas macroestruturas do cristalino, bem como nas planícies costeiras descontínuas de origem marinha e fluvial.

No território brasileiro, as estruturas e as formações litológicas são dominantemente antigas, mas as formas do relevo são mais recentes. A partir dos efeitos da tectônica meso-cenozóica os desgastes erosivos estão continuamente produzindo novas feições ao modelado. Assim sendo, as formas grandes e pequenas do relevo brasileiro têm como mecanismo genético, de um lado, as formações litológicas e os arranjos estruturais antigos, e, de outro, os processos mais recentes reativados pela movimentação dos megablocos estruturais representados pelas placas litosféricas e o constante desgaste erosivo promovidos pelos climas anteriores e atuais. Grande parte das rochas e estruturas que sustentam as formas do relevo brasileiro são anteriores à atual configuração do continente sul-americano, que passou a ter o formato atual com os efeitos da orogenia andina que por sua vez é associada à abertura do Oceano Atlântico, a partir do Jurássico (130 Ma).

De forma simplificada, as grandes estruturas que definem os macro-compartimentos do relevo encontrados no Brasil e na América do Sul, são os crátons ou plataformas, os cinturões orogênicos antigos e recentes, as grandes bacias sedimentares paleo-mesozóicas e as bacias sedimentares cenozóicas.

As plataformas ou crátons correspondem aos terrenos mais antigos e rebaixados por centenas de milhões de anos por atividades erosivas. Constituem-se numa grande complexidade litológica e estrutural, prevalecendo as rochas metamórficas muito antigas do Pré-Cambriano Médio a Inferior (Arqueozóico), bem como rochas metamórficas e intrusivas antigas do Pré-Cambriano Médio a Superior (Proterozóico) e também rochas sedimentares datadas do Pré-Cambriano Superior (Proterozóico), que recobrem residualmente pequenas áreas dos terrenos dos crátons ou plataformas. Essas áreas de plataformas antigas correspondem ao cráton ou plataforma Amazônica, do São Francisco, Uruguaio-sul-rio-grandense e Patagônia, tendo maior expressividade e continu- 
idade territorial o Cráton Amazônico.

Os cinturões orogenéticos, que correspondem às extensas faixas de estruturas dobradas no território brasileiro, são muito antigos, correspondendo a diversas fases ao longo no PréCambriano Superior (Proterozóico). Esses cinturões representam faixas de sutura entre crátons e consolidam em seu conjunto os terrenos do Pré-Cambriano da América do Sul. Estão representados pelas faixas de dobramentos do Atlântico, de Brasília e Paraguai-Araguaia. Essas três antigas cadeias montanhosas foram geradas pela dinâmica crustal do Proterozóico. Constituíam bacias sedimentares de bordas de continentes que, por pressões dos deslocamentos crustais de grandes blocos estruturais, foram transformadas em cadeias orogenéticas longas, estreitas e elevadas à semelhança do que se observa na atualidade em cadeias montanhosas como dos Alpes, do Himalaia, dos Andes, das Rochosas, entre outras. Passaram por dobramentos, metamorfismos regionais, magmatismos com intrusões e vulcanismos, mas também sofreram e continuam passando por desgastes erosivos dos últimos 550/600 milhões de anos (Fanerozóico), encontrando-se muito rebaixadas pelas várias fases desnudacionais, mas ainda guardando aspecto montanhoso e serrano em grandes extensões.

O terceiro tipo de estrutura, que ocorre no território brasileiro e na América do Sul, é o das grandes bacias sedimentares paleo-mesozóicas, como a Amazônica Oriental, do Parnaíba, do Paraná e do Parecis. Quando essas bacias foram geradas, os terrenos do continente sulamericano não apresentavam o formato e não estavam na posição geográfica atuais, mas sim em posições altimétricas mais baixas. Os depósitos marinhos, glaciais, desérticos e continentais formaram as rochas sedimentares das três grandes bacias. Assim, nelas são encontrados, sobretudo arenitos de diferentes idades e granulações, intercalados por camadas de siltitos, argilitos, folheIhos, conglomerados e calcários, entre outros. Especificamente, na Bacia do Paraná ocorreu, no Jurássico, extensivo derrame de lavas vulcânicas predominantemente básicas (basaltos), que se acomodaram sobre as camadas sedimentares em planos pseudo-horizontais estratificados à semelhança das estruturas sedimentares. Os "pacotes" sedimentares que formam as grandes bacias sul-americanas tiveram interrupção de sedimentação generalizada no fim do Mesozóico (Cretáceo). Deste modo, os últimos estratos que compõem o pacote sedimentar destas bacias são os arenitos de origem continental datados como do Cretáceo. Na Bacia do Paraná, por exemplo, os arenitos do Grupo Bauru, na Bacia do Parecis, os arenitos do Grupo Parecis, bem como nas demais grandes Bacias do Parnaíba e Amazônica Oriental. Os sedimentos que preenchem essas grandes bacias sedimentares têm suas origens nos desgastes dos relevos mais elevados dos cinturões orogenéticos e dos crátons, que passaram por constantes, porém variados processos erosivos de natureza climática diversas, como climas quentes e úmidos, desérticos, glaciais e seus respectivos depósitos que se deram em ambientes marinhos, glaciais, desérticos e continentais.

É a partir do Jurássico, do Cretáceo e ao longo do Cenozóico, que há uma significativa mudança nos rumos dos processos geotectônicos globais com reflexos decisivos na conformação do continente sul americano e consequentemente na estrutura geológica e na gênese do relevo do que viria a se constituir, no Terciário e no Quaternário, a América do Sul. É no Cenozóico que se formam as bacias sedimentares recentes, a cordilheira andina, os soerguimentos epirogenéticos com reativação dos falhamentos antigos e a formação de escarpas na parte central e leste do continente. Desdobra-se, a partir dessa tectônica meso-cenozóica, a intensificação da retomada ero- 
siva decisiva nos processos de rebaixamento dos planaltos e das serras do centro-leste do continente. É, portanto, o Cretáceo um divisor temporal importantíssimo para se desvendar os enigmas da morfogênese do relevo sul-americano.

Os depósitos do Cenozóico são encontrados mais extensivamente na parte ocidental da Bacia Amazônica (Solimões), nas Bacias do Orenoco, do Paraguai-Paraná e nos litorais dos oceanos Atlântico e Pacifico. Formaram-se também bacias sedimentares terciário-quaternárias nos grábens ou rift-valleys geradas concomitantemente com as respectivas depressões tectônicas como as do médio vale do rio Paraíba do Sul, nos Estados do Rio de Janeiro e São Paulo, Alto Rio Tietê, na região metropolitana de São Paulo, baixo vale do Rio Ribeira do Iguape, em São Paulo, entre várias outras no território nacional, principalmente na faixa dos dobramentos do Atlântico.

Na perspectiva das formações geológicas e suas respectivas datações, a história geológica do continente sul-americano está suficientemente desvendada em suas grandes linhas. Há absoluta clareza sobre a sequência genética dos grandes eventos geotectônicos e das origens e datas das litologias que sustentam o arcabouço estrutural do continente. Não se pode, entretanto, afirmar o mesmo para a história da geomorfologia sul-americana. As informações geológicas relativas aos tipos de materiais litológicos têm códigos e critérios consolidados internacionalmente para identificá-los e datá-los, sempre partindo do mais antigo e mais baixo na coluna cronoestratigráfica. Já as identificações e datações relativas à geomorfologia não são criteriosamente estabelecidas e a grande dificuldade e o enorme desafio estão no fato de que não se quer datar materiais (rochas, solos), mas sim as formas do relevo e estas, por si só, são abstratas, ou seja, só existem porque há materiais que lhes dão suporte.

Ocorre que os materiais não obrigatoriamente têm a mesma idade das formas de relevo que as sustentam. Por exemplo, os planaltos e as serras esculpidos na faixa de dobramentos do Atlântico não têm mesma idade das rochas e das estruturas que sustentam tais formas. Não se pode, portanto, atribuir aos planaltos e às serras deste cinturão orogenético, a mesma idade de sua origem, ou seja, do Pré-Cambriano Superior (Proterozóico), pois os processos de desgaste dessa megaestrutura estão atuando por mais de 550 milhões de anos, desde a sua geração, erodindo e rebaixando o relevo originalmente produzido pela tectônica. Conclusão: quando se diz que o Cinturão Orogenético do Atlântico tem em sua litologia e arranjo estrutural idade entre 550 e 1.5 biIhão de anos, só se está se referenciando à idade geológica, pois a idade geomorfológica é bem mais recente, considerando o fato de que os rebaixamentos erosivos estão atuantes ao longo de todo o Fanerozóico (550 Ma).

Responder, portanto, qual é a idade do Planalto Sul Mineiro, do Leste Paulista ou Fluminense é dominantemente conjetural ao se tomar como base as informações geológicas relativas às idades e às gêneses das litologias e das estruturas, bem como os eventos tectônicos antigos e recentes. Neste contexto, há, portanto, intervalos grandes de idades das formas do relevo que são possíveis ou prováveis, mas extremamente difíceis de serem comprovadas científica e tecnicamente. As datações dos depósitos do Terciário-Quaternário existentes nas bacias sedimentares incrustradas nas depressões tectônicas (rifts), como as de Taubaté, de Rezende, de Itaboraí, de Curitiba, do Pantanal de Mato Grosso, dentre inúmeras outras, bem como em terraços fluviais, certamente oferecem maior concretude na interpretação da gênese e das idades desses depósitos e, consequentemente, dos processos erosivos correspondentes e das idades prováveis das 
formas do relevo desses lugares.

No entanto, deve-se destacar que há nesta perspectiva de datações de materiais (rochas e sedimentos) resultados coincidentes ou, pelo menos, muito próximos das datações das formas de relevo associadas. Uma delas é relacionável às formas e aos materiais gerados por deposições recentes, onde depósitos inconsolidados, de origem marinha ou fluvial, formando planícies e terraços, têm nos materiais idades coincidentes, ou seja, formas e materiais têm a mesma idade. Como exemplo, os sedimentos arenosos de cobertura do Pantanal do Rio Paraguai de origem fluvial têm suas idades datáveis com rigor técnico indicando que são do Quaternário (Pleistoceno e Holoceno) e nesse caso pode-se ter maior certeza sobre a idade das formas do relevo do Pantanal, porque são coincidentes com as dos materiais de suporte que estão próximos da superfície atual. Isso, entretanto, não resolve a gênese da bacia do Pantanal como um todo, pois é preciso ter-se os dados sobre os sedimentos mais profundos e conhecer a cronoestratigrafia de todo pacote.

Há uma outra condição, em que se pode ter mais certeza da idade da forma devido a idade do material que lhe dá sustentação, que são os arenitos do Cretáceo que sustentam as Chapadas das bordas das grandes bacias sedimentares do território brasileiro. Pode-se considerar que as Chapadas, localizadas nas bordas das bacias sedimentares do Paraná, do Parecis, do Parnaíba, de topos absolutamente planos e mantidas por rochas de arenitos datados do Cretáceo (65 Ma), têm a mesma idade das rochas que thes dão suporte. A partir desses fatos geológicogeomorfológicos e das formas de relevo produzidas por erosão, que se encontram em posições topográficas mais baixas e ao redor dos topos das chapadas, são supostamente de idades mais novas e posteriores ao Cretáceo. Deste modo, os planaltos, os patamares estruturais e as depressões periféricas circundantes, são de idades entre o Cretáceo e o Holoceno, ou seja, têm idades que se inserem no Terciário e no Quaternário.

Em função desses marcadores referenciais do tempo geológico, tornou-se frequente nas datações conjeturais e, portanto, relativas da geomorfologia, identificar formas do relevo do território brasileiro referente aos níveis mais elevados como genericamente do Cretáceo e todos os níveis mais baixos, de acordo com as altimetrias e as litologias, como sendo de idades mais recentes, ou seja, do Terciário ao Quaternário. A despeito de interpretações muito lineares, fizeram-se muitas datações relativas seguindo-se a aparente lógica de que os degraus mais elevados, mas que estão abaixo dos topos aplainados do Cretáceo, são do Terciário mais antigo (Paleoceno/Eoceno); os degraus intermediários, do Terciário recente (Mioceno/Plioceno); e, os degraus mais baixos, do Quaternário (Pleistoceno/Holoceno). Isto foi sendo aplicado tanto para os relevos esculpidos em bacias sedimentares, como os desenvolvidos sobre os Cinturões Orogenéticos e Crátons. É evidente que essas datações relativas carecem de maior rigor cronológico, até porque foi preciso também considerar que os movimentos crustais são dinâmicos. Decisivamente ao longo do Cretáceo e Cenozóico não só a Cordilheira Andina surgiu formando o arcabouço do oeste do Continente, como seus reflexos interferiram na movimentação tectônica em todo o restante do bloco continental promovendo soerguimentos, reativações de falhas antigas, basculamentos de blocos, escarpamentos, rift valeys (grábens e horsts), e induzindo ou acelerando os processos erosivos com desnudação e consequente rebaixamento do relevo.

Diante disso, o desafio para se entender a morfogênese e a cronologia do relevo do Brasil e da América do Sul como um todo, está sempre em se considerar a tectônica antiga e os arranjos 
estruturais decorrentes dela, os processos desnudacionais e os consequentes rebaixamentos morfológicos, as atividades tectônicas mais recentes, sobretudo do Cenozóico, como os soerguimentos, os basculamentos, os falhamentos, as distensões responsáveis pelas atividades da neotectônica. Para aumentar a complexidade da análise geomorfológica, na perspectiva genética, é preciso contemplar o fato de que os processos desnudacionais são ativados também pelas oscilações e mudanças climáticas ao longo do tempo geológico. Climas frios, quentes, secos, úmidos, glaciais são agentes e indicadores de diferentes processos erosivos e deposicionais.

As pesquisas e as análises geomorfológicas são, por natureza, complexas, imprecisas e, dominantemente, conjeturais, ainda que, na atualidade, já se disponha de inúmeras técnicas para identificar e medir processos e datar materiais, os quais, no entanto, não indicam, obrigatoriamente, a idade da forma. Assim, mesmo com todo avanço tecnológico, as interpretações morfogenéticas e morfocronológicas são relativas e com razoável grau de imprecisão. Dessa forma, ao apresentar-se no presente artigo aspectos e características do relevo do continente sul-americano, procede-se a identificação geral das idades e gêneses das formas, típica de análises conjeturais de base empírica, o que de fato constitui o grande e eterno desafio da pesquisa geomorfológica.

\section{Superfícies de erosão: primeiras contribuições}

As discussões sobre a evolução do relevo brasileiro são recorrentes e passíveis de constantes revisões. Neste sentido, Ross (2013) ressalta que a respeito dos processos tectônicos e erosivos, vários pesquisadores deram significativas contribuições, entre eles estão, Moraes Rego (1933), De Martonne (1943), Ruellan (1952), Freitas (1951), Ab'Saber (1949, 1957, 1958, 1960, 1964, 1969, 1984, 1998 e 2001), Almeida (1949, 1958, 1964, 1976, 1988), King (1956), Bigarella (1965), Silveira (1953), Ross (1987, 1989, 1991, 1997, 2002), entre outros, quase todos tratando das questões geomorfológicas na fachada Atlântica do Sudeste Brasileiro, ou seja, nas terras do Cinturão Orogenético do Atlântico e nas bordas das bacias sedimentares, com destaque para a bacia do Paraná.

Dentre as várias contribuições, Ross (2013, p. 12) destaca que o trabalho de De Martonne (1943), denominado 'Problemas morfológicos do Brasil tropical úmido', "[...] apesar de ter considerado os efeitos da tectônica que afetou o Leste-Sudeste do Brasil, deu grande peso para os níveis morfológicos que identificou como produto de diversas fases de erosão a que denominou de Superfícies Pré-Permiana; dos Campos; das Cristas Médias; e Neogênica."

A Superfície Pré-Permiana, considerada por De Martonne (1943) como superfície de erosão fossilizada, corresponde a um plano inclinado que mergulha sob os sedimentos carboníferos e permianos da Bacia do Paraná, na altura dos 550-600 m. A Superfície dos Campos basicamente estabelecida nos topos retilinizados da Serra da Mantiqueira, balizada em torno dos 1.400-1.500 $\mathrm{m}$, referenciando-se à vegetação de campos naturais de Campos do Jordão, e de Ribeirão Fundo, associada possivelmente ao Cretáceo. A Superfícies das Cristas Médias, cujos topos dos morros e serras estabelecem uma superfície plana imaginária que se encontra entre 1.000-1.100 m, relacionada ao Paleógeno, ou seja, ao Terciário Inferior. Este nível de erosão tangencia os topos das 
serras como de Jaraguá, do Japi, da Cantareira, entre outras, cujas partes mais elevadas encontram-se nas altimetrias acima citadas. Projetando-se para o Centro-Oeste de São Paulo, essa superfície tangencia o topo do front da Cuesta de Botucatu - São Carlos, onde as altitudes oscilam em torno dos 900-1.000 m. Tal projeção sugere, portanto, que a Superfície das Cristas Médias também truncou por erosão os trechos atualmente planos e mais altos da Bacia do Paraná, cujos testemunhos são encontrados nos limites do Planalto Ocidental Paulista com a faixa escarpada das frentes de cuestas que também delimitam a Depressão Periférica Paulista, a oeste. Esta superfície, na área dos terrenos cristalinos do leste paulista, coincide com os blocos rochosos associados a intrusões de corpos graníticos (Serras da Cantareira, do Itapeti, de São Roque, de São Francisco, do Itaqui e parte sul do Japi) ou com blocos estruturais metamórficos rígidos de quartzitos (Jaraguá, Voturuna e Japi) que oferecem maior resistência aos processos de meteorização e, consequentemente, ao desgaste, tanto por ação química quanto mecânica. Por último, a superfície Neogênica, considerada como sendo os terrenos que se nivelam entre 800-900 m., compreende trechos do vale do Paraíba, do Alto Tietê, projetando-se ligeiramente inclinado para oeste, correspondendo ao nível dos topos das colinas da Depressão Periférica. Esta superfície datada, portanto, entre o Terciário Superior e o Quaternário Inferior (Plioceno-Pleistoceno), coincide com o que se denominou de Superfície de São Paulo por Almeida (1964), que envolve tanto os terrenos cristalinos quanto os sedimentares da Bacia de São Paulo, cujos setores mais altos (800-830 m) nivelaram-se com trechos do cristalino ligeiramente aplanado dos arredores da cidade de São Paulo. Há, portanto, uma preocupação clara em definir idades às formas do relevo do leste paulista valorizando-se os níveis morfológicos e os aplanamentos do Terciário ao Quaternário (ROSS, 2013).

Lester King (1956), com o trabalho "Geomorfologia do Brasil Oriental", formulou uma interpretação da evolução do relevo brasileiro, associando-o ao do continente africano. Sua contribuição merece atenção, principalmente pelo fato de introduzir no País uma outra linha de interpretação - a dos policiclos de erosão, de utilizar na interpretação da gênese das formas de relevo do Brasil os conceitos de Pedimentos e de Pediplanação, bem como o de considerar em suas análises o efeito das fases de soerguimentos generalizados do bloco continental, alternados com fases de erosão pela regressão de escarpas e pedimentação (ROSS, 2013).

A chave de interpretação do relevo brasileiro elaborada por Lester King parte da afirmação de que o "Elemento fundamental do cenário brasileiro é a vasta planície produzida por denudação entre o Cretáceo Inferior e o Terciário Médio, que após soerguida passou a ser dissecada pela erosão policíclica". Essa vasta planície foi denominada de "Superfície Sul-Americana" ou de "Peneplanação Sul-Americana", transformando-se na chave de entendimento da evolução morfogenética cenozóica do relevo brasileiro. Na sequência, interpretou que os testemunhos dos ciclos anteriores, como o Gondwana (Cretáceo Inferior ao Jurássico) e o Pós-Gondwana (Cretáceo Superior), encontram-se fossilizados pelos depósitos do Cretáceo. Os ciclos Velhas (Terciário Superior) e Paraguaçu (Pleistoceno) dissecaram a Superfície Sul-Americana e com isso os seus testemunhos estão embutidos nesta última, que foi mais ampla (ROSS, 2013).

O trabalho de Bigarella, Mousinho e Silva (1965), a respeito das superfícies de erosão, publicado na obra "Pediplano, Pedimentos e seus Depósitos Correlativos no Brasil", procurou modelizar a interpretação da evolução do relevo brasileiro. Os autores, a partir de estudos efetuados no Sul e Sudeste do Brasil, sobretudo na região da Serra do Mar, propõem três grandes fases erosi- 
vas ocorridas por pediplanação. Tal interpretação apoia-se na influência de Lester King e Walter Penck e tem a concepção de que as vertentes evoluem por recuo paralelo em ambientes áridos e semiáridos, gerando nesse processo superfícies aplanadas e arrasadas por erosão. Tais superfícies se definem através dos pedimentos e a coalescência destes definem os pediplanos. A atividade erosiva exercida de um lado implica na deposição dos sedimentos e, de outro, dos depósitos correlativos (ROSS, 2013).

Deste modo, fica implícito que a cada fase erosiva deve existir uma correspondência de sedimentação. Os autores identificam três superfícies de Pediplanação, denominadas de Pd1, Pd2 e Pd3, e que devem corresponder a três significativos depósitos correlativos, P1, P2 e P3. Com a preocupação em estabelecer a relação entre gênese e idade, propõem para o $\mathrm{Pd} 3$, a idade no Cretáceo-Eoceno, coincidindo com a sedimentação do Cretáceo para todo o Brasil. Essa superfície chamada de Pd3 corresponde à Superfície de Cimeira, chamada, por De Martonne, de Superfície dos Campos e das Cristas Médias; de Sul-americana, por King e, de Superfície Japi, por Almeida. Estas superfícies mostram-se, segundo os autores, deformadas por efeito da tectônica e da dissecação Cenozóica. A superfície Pd2 teria se processado a partir do Terciário Médio, correspondendo às superfícies interplanálticas periféricas com ciclicidade de fases secas e úmidas. Esta fase grosseiramente corresponde ao ciclo Velhas, de King, quanto à idade. A abertura das depressões periféricas, que definem níveis mais baixos nos contatos do cristalino com os sedimentos da bacia do Paraná, Parnaíba e Amazonas, corresponde ao que Ab'Saber denominou de superfície Neogênica. A superfície Pd1 corresponde às áreas em processo de esculturação definidos morfologicamente através de alvéolos embutidos na superfície Neogênica do Sul e Sudeste, bem como os tabuleiros litorâneos do Nordeste, que corresponderia ao ciclo Paraguaçu, de Lester King (ROSS, 2013).

Contribuições importantes para o entendimento da evolução do relevo brasileiro foram dadas por Ab'Saber (1949-1960-1972) no âmbito das superfícies de erosão. A identificação de regiões no Brasil com marcas de circundesnudações cenozóicas foi a primeira etapa para, posteriormente, estabelecer uma sequência de níveis ou superfícies de erosão, a que denominou de "Posição das Superfícies Aplainadas do Planalto Brasileiro". Nessa proposta, Ab’Saber (1960) identificou quatro níveis ou superfícies de aplainamento, assim denominadas: 1 . Superfícies de Cumiada ou Cimeira, as quais englobam tanto as Superfícies de Campos quanto as Cristas Médias anteriormente identificadas por De Martonne. Para Ab'Saber, estas superfícies correspondem a antigas áreas de erosão, atualmente posicionadas em níveis elevados (acima de $1.000 \mathrm{~m}$ ) em face dos processos tectogenéticos - arqueamentos devidos à epirogênese pós-cretácea; 2. Superfícies Intermontanas, Interplanálticas ou embutidas, que correspondem às grandes depressões periféricas que circundam as bacias sedimentares, esculpidas ao longo do Neogeno (PliocenoPleistoceno); 3. Superfícies Fósseis em Exumação, correspondentes às antigas superfícies de aplanamento que foram encobertas por sedimentos das grandes bacias sedimentares e que atualmente se encontram em processo de exumação; 4. Superfícies de Eversão, correspondentes àquelas áreas que representam superfícies antigas exumadas. Compreendem depressões como a Cuiabana, a Sertaneja e as da Amazônia norte e sul que se encontravam encobertas por sedimentos das bacias sedimentares e que, atualmente, estão expostas por efeito de fases erosivas subsequentes.

Conforme Ross (2013), o professor Aziz Nacib Ab'Saber redefine, em 1972, as superfícies 
aplainadas na participação da compartimentação do Planalto Brasileiro, valorizando a tipologia das depressões que estão nos rebordos das grandes bacias sedimentares preocupando-se com a classificação genética. Assim, surgem as denominações de: Depressões Periféricas Subsequentes, Depressões Monoclinais, Depressões Marginais com forte Eversão e Depressões Marginais com Eversão e Formação de Bacias Detríticas.

Como se pode perceber, a análise da morfogênese do relevo brasileiro depara-se com muitas dificuldades para interpretar a dinâmica e a idade dos processos geradores das macroformas. A discussão, desde tempos que retrocedem à primeira metade do século $X X$, procura explicações para a evolução do relevo em escala regional, considerando sempre a oposição entre processos tectônicos geradores dos soerguimentos, dos arqueamentos, dos basculamentos, das epirogêneses, das orogêneses e dos processos esculturais, erosivos, desnudacionais, ou, ainda, de rebaixamento, em uma disputa permanente entre tectônica, de um lado, e processos morfoesculturais, de outro.

\section{O relevo brasileiro e as contribuições recentes}

Ao promover uma revisão dos conhecimentos geomorfológicos do território brasileiro, Ab'Saber (1998) discorre sobre vários aspectos que considera fundamentais para entender a morfogênese, considerando tanto aspectos estruturais antigos e recentes como esculturais, com destaque para os atuantes no Terciário e no Quaternário. Apresenta algumas conclusões, entre as quais se ressalta:

A plataforma brasileira composta de rochas granitizadas ou metamorfizadas em feixes de velhíssimos dobramentos, e incluindo vastas bacias intracratônicas, formadas entre o Devoniano Inferior e o Cretáceo Inferior, eram partes de um gigantesco contínuo geológico, reconhecido pela expressão 'Continente de Gondwana'.

\section{$[\ldots]$}

Com a fragmentação do continente de Gondwana e, mais tarde, nos fins do Terciário, com o soerguimento da barreira ocidental constituída pela Cordilheira Andina, toda a drenagem antiga tributária da fachada pacífica teve que se inverter [...] para a fachada atlântica.

\section{[...]}

Na história da fragmentação megatectônica do continente afro-brasileiro, têm importância os grandes derrames de lavas basálticas [...] produtos de um vulcanismo maciço, vinculado ao início da tectônica de placas que deu origem à separação Afro-Brasília.

\section{$[\ldots]$}

Houve uma dualidade opósita entre a sedimentação cretácea terminal acontecida no dorso da plataforma brasileira [...] e os espessos depósitos acumulados nas fossas tectônicas da fachada Atlântica brasileira. Enquanto os depósitos mesozóicos continentais eram exclusivamente lacustres, fluviais e flúvio-lacustres, os sedimentos das bacias tectônicas da plataforma continental eram predominantemente marinhos ou semi-marinhos, tornando possível a geração de formações oleiginas 
No momento terminal da separação entre África e Brasil, a plataforma brasileira estava em nível tectônico mais baixo do que o atual [...]. Mas, certamente haviam setores abaulados nos terrenos cristalinos interpostos entre as bacias sujeitas a subsidência residual, ao fim do Cretáceo. Estas bacias sedimentares que fecharam os episódios deposicionais [...] localizam-se parcialmente sobre setores das grandes bacias paleomesozóicas [...].

As principais depressões periféricas, existentes no entorno ou margens de bacias sedimentares soerguidas no território brasileiro, foram escavadas na primeira metade do Terciário (Paleogeno). O incentivo principal para ativar o processo de desnudação marginal, incluindo os sistemas de circundesnudação, foi a fase de soerguimento epirogenético pós-cretácea e pré-pliocênica; ao término da qual restaram vastas áreas de aplainações interplanálticas [...] tendo como protótipos a depressão periférica paulista, as depressões interchapadas e intermontanas dos sertões do Nordeste, e as depressões periféricas da metade sul da terra gaúcha (AB'SABER, 1998, pp. 88-90).

Nesse contexto, Ab'Saber (1998) faz referência às superfícies aplainadas do Brasil, como as superfícies fósseis em processo de exumação, superfícies de cimeiras desdobradas e superfícies interplanálticas de níveis ligeiramente desdobrados. Chama a atenção para superfícies como a identificada e denominada por Caster, em 1947, como paleoplano pré-devoniano, ou ainda da superfície identificada e denominada por De Martonne (1943), como superfície fóssil précarbonífera superior. Essas superfícies fósseis estão parcialmente expostas na plataforma brasileira ao longo dos rebordos marginais das atuais bacias sedimentares paleomesozóicas.

Com relação às superfícies de cimeira, ou seja, aqueles níveis morfológicos mais elevados do território brasileiro, Ab'Saber (1998, p. 91), argumenta que "As Superfícies de Cimeiras [...] foram geradas a partir dos rebaixamentos desnudacionais dos fins do Cretáceo, sendo muito bem marcadas nas terras altas do Escudo Brasileiro e no reverso das cuestas concêntricas das bacias do Paraná e Parnaíba", e especifica que "[...] foram reconhecidas nos altos do Espinhaço, por Harder \& Chamberlin (1915), no topo da Mantiqueira e Bocaina por De Martonne (1943), sob o nome de Superfícies dos Altos Campos com um desdobramento mais baixo designado por Superfícies das Cristas Médias pelo próprio De Martonne (1943), modificada para Superfície do Japi, por Almeida (1951)". O autor segue descrevendo inúmeros outros exemplos onde esta última superfície foi identificada, com destaque paras as bordas elevadas e planas (Chapadas) das grandes bacias sedimentares do Paraná, Parnaíba e os topos dos relevos residuais do nordeste brasileiro, entre os quais as Chapada do Araripe, de Ibiapaba, de Baturité, de Teixeira, as quais, segundo o autor, testemunham "[...] importante período de aplainamento desfigurado por deformações tectônicas e processos desnudacionais responsáveis pela notável expansão dos aplainamentos interplanálticos sertanejos".

Ab'Saber ressalta em suas conclusões sobre a morfogênese do relevo brasileiro que "[...] terminadas as grandes aplainações do fim do Terciário, embutidas em depressões interplanálticas, ocorreu uma reativação de soerguimentos de grande abrangência espacial e de baixa amplitude altimétrica" (AB'SABER, 1998, p. 93). Conforme sua interpretação, com a reativação tectônica através desse "[...] soerguimento pós-plioceno, foram elaborados níveis de erosão intermediários ocorridos entre o Pleistoceno Inferior e o Pleistoceno Médio. Do Pleistoceno Médio para o Pleistoceno Superior cessaram os soerguimentos de conjunto, substituídos por casos de tectônica quebrável irregular, muito raros e localizados" (AB'SABER, 1998, p. 93). Acrescenta ainda que, "[...] a partir do Pleistoceno Médio para o Superior, passaram a predominar amplos efeitos paleo- 
climáticos e ecológicos relacionados as rápidas e sucessivas flutuações do nível do mar, sobretudo no intervalo decorrido entre 110 mil anos antes do presente (A.P.) até nossos dias" (Idem).

Ross (1991) ao tratar da diversidade genética dos níveis morfológicos ou topográficos, posiciona-se sobre o fato de que

[...] fica evidente que não se pode estabelecer uma relação direta e absoluta entre Superfícies de Aplanamento, os diferentes níveis morfológicos ou topográficos e as idades das formas. "Embora se possam estabelecer algumas generalizações de âmbito regional, admitindo-se que os níveis aplanados ou pelo menos retilinizados dos topos dos geossinclineos (leia-se cinturões orogenéticos), sejam testemunhos de fases erosivas antigas (Pré-Cenozóico) e que as depressões e superfícies embutidas e de bordas das grandes bacias sedimentares sejam de idades mais recentes (Terciário/ Quaternário) [...] (ROSS, 1991, p. 14).

Em outro trabalho, publicado no mesmo ano, sobre o contexto geotectônico e a morfogênese da Província Serrana, em Mato Grosso, Ross apresenta um quadro síntese da evolução do relevo regional, destacando a seguinte sequência morfocronológica:

1 - No Pré-Cretaceo, houve "Diversas fases erosivas que deixaram como testemunhos superfícies aplanadas e ou niveladas no topo da Província Serrana e no Planalto das Bacias do Rio Casca e Mutum" (ROSS, 1991a, p.35). Essas superfícies erosivas ou de aplanamento cortam em discordância erosiva/estrutrural os metassedimentos dos Grupos Alto Paraguai (Província Serrana) e Cuiabá (Depressões Cuiabana e Planalto do Casca-Mutum);

2 - No Cretáceo, ocorre o fecho de Sedimentação dos Grupos Parecis e Bauru que dão suporte às Chapadas dos Parecis e Guimarães, bem como o recobrimento em nítida discordância erosiva, dos topos aplanados e preservados das anticlinais da Província Serrana, que representa as estruturas dobradas e falhadas do Cinturão Orogenético ParaguaiAraguaia (ROSS, 1991a);

3 - Do Cretáceo Superior ao Terciário Médio, há o soerguimento da Plataforma Brasileira (Sul-americana), ou seja, a epirogênese Pós-Cretáceo, o que promoveu a reativação de faIhas antigas e o basculamento de blocos, gerando desnivelamentos na Província Serrana, onde observou-se três níveis morfológicos com topos planos ou retilinizados, cujos desníveis foram gerados pela tectônica (ROSS, 1991a);

4 - Do Terciário Médio ao Pleistoceno, consolida-se a abertura das Depressões do Alto Paraguai, Cuiabana e Periférica do Arinos. Este processo desnudacional exumou parcialmente os metassedimentos dos grupos Cuiabá e Alto Paraguai, bem com os basaltos do Patamar Estrutural de Tapirapuã, erodindo e/ou removendo parcialmente os arenitos do Grupo Parecis, no Planalto e na Chapada dos Parecis, e do Grupo Bauru, no Planalto e Chapada dos Guimarães (ROSS, 1991a);

5 - No Pleistoceno, ocorreu a deposição dos sedimentos preferencialmente arenosos da Formação Pantanal sobre a superfície aplanada das Depressões do Alto Paraguai e Cuiabana (Ross, 1991a);

6 - No Pleistoceno mais recente e no Holoceno, a continuação dos processos de sedimentação fluvial/lacustre em regimes de leques aluviais gera a Planície do Pantanal e ao mesmo tempo dissecando as terras pouco mais altas do entorno, inclusive os próprios sedimentos da Formação Pantanal ao longo da Depressão do Alto Paraguai, drenada pelos rios Para- 
guai, Sepotuba e Pari. Nesta área há uma clara retomada erosiva possivelmente por efeitos de pequenos soerguimentos tectônicos recentes ou abaixamentos do nível de base do rio Paraguai a jusante, gerando terraços inclusive nos pequenos tributários de alto curso (ROSS, 1991a).

Em publicação mais recente sobre a morfogênese da Chapada dos Guimarães, Ross (2014) conclui que a relativa preservação do topo aplanado da Chapada dos Guimaraes é uma herança da morfologia da fase em que houve o fecho de sedimentação do Grupo Bauru, no Cretáceo. Os processos esculturais/desnudacionais que ocorreram nessa região se deram simultaneamente aos arqueamentos/soerguimentos do chamado "Arco de São Vicente", ao longo do Cenozóico, e os materiais argilosos e concrecionários que recobrem a superfície no nível dos 850/900m, definidos como Latossolos Vermelhos, são produtos da pedogênese e não obrigatoriamente de novos depósitos detrítico-lateríticos do Terciário-Quaternário.

Os trabalhos de Ross (2001), na faixa de dobramentos Brasília ou Cinturão Orogenético de Brasília, referentes às morfologias e à gênese dos relevos do norte Goiano e Distrito Federal, podem ser assim resumidos: os relevos montanhosos constituídos por serras, planaltos e depressões intermontanas, que configuram a geomorfologia da área, se encaixam perfeitamente na interpretação genérica de que a faixa de dobramentos que compõe este relevo é parte de um processo geotectônico do Pré-Cambriano Superior (Proterozóico), ocasião em que ocorreram dobramentos, metamorfismos e intrusões subjacentes, produzindo uma vigorosa cadeia montanhosa do tipo cordilheirano. Após essa formação, os processos erosivos, à semelhança do que ocorreu em outras áreas do atual território nacional, rebaixaram as montanhas que no passado possivelmente atingiriam altitudes próximas dos 3000/4000m e que hoje estão entre 800/900m em média ou em setores mais restritos com 1400/1700m.

O que se observa na atualidade são os relevos montanhosos, esculpidos sobre as rochas que compunham "as raízes" dos dobramentos da antiga cordilheira. Vislumbra-se de forma genérica que as atuais Serras Dourada, da Mesa, das Traíras, Branca, Canastra e Chapadas dos Veadeiros e Brasília, são produtos residuais das diversas fases de rebaixamento erosivo dessa cordiIheira. Entremeiam essas Serras e Chapadas corredores rebaixados e praticamente planos, posicionados em níveis altimétricos ao redor dos 400/500m definindo Depressões Intermontanas que se articulam para norte ao longo da bacia hidrográfica do Tocantins com a Depressão do Tocantins.

As terras elevadas são sustentadas por sequencias de anticlinais e sinclinais fortemente erodidos. Esses testemunhos dos antigos dobramentos são mantidos nas bordas por cristas assimétricas de quartzitos e o interior das anticlinais escavadas por formas em morros com topos convexos amplos e sustentados por granitos, representados pelas massas intrusivas subjacentes, cujos processos erosivos, durante milhões de anos, os colocaram à luz da superfície. As terras mais baixas e aplanadas, que configuram as depressões intermontanas, são dominantemente esculpidas em rochas metamórficas menos resistentes, como os micaxistos, filitos e outras, parcialmente coincidentes com a val de sinclinais bastante erodidos ou ainda de anticlinais escavados e muito rebaixados. Observa-se, entretanto, ao longo da Depressão do Tocantins e de setores das Depressões intermontanas, sedimentos superficiais, de material fino (areias finas e argilas), com horizontes concrecionários e espessuras que chegam a $20 \mathrm{~m}$, repousando sobre um plano préexistente da superfície destas depressões. Como essas coberturas são identificadas como do 
Terciário-Quaternário e estão dissecadas pela rede de drenagem atual, interpreta-se que após sua origem, houve uma retomada erosiva que pode ter sido induzida por efeitos de tectônica recente ou então do rebaixamento do nível de base do rio Tocantins ou ambos. Esta interpretação é reforçada pela existência de terraços fluviais com 20/30 metros de entalhamento, como ocorre nesse rio, na região de Porto Nacional, que hoje estão submersos pelas águas da barragem da hidrelétrica do Lajeado. Para o sul, nessas estruturas, estão as superfícies aplanadas e elevadas das Chapadas dos Veadeiros, de Brasília, o topo plano da estrutura circular de Caldas Novas, o topo plano da Serra da Canastra, que associado aos topos erodidos e parcialmente rebaixados, retilinizados e nivelados das anticlinais e sinclinais, permitem concluir que houve fases erosivas intensas e longas no Pré-Terciário que aplanaram o relevo montanhoso preexistente.

Esses processos foram responsáveis por vigorosos rebaixamentos e aplanamentos que colocaram o atual relevo em posições topográficas mais baixas e, portanto, diferentes das atuais. $\mathrm{O}$ fato de se ter atualmente superfícies com relevo quase plano nos topos atuais do Cinturão Orogenético de Brasília, bem como os topos e cristas retilinizadas das anticlinais e sinclinais, indicam que após esses aplanamentos, todo o conjunto foi reativado e soerguido, retomando ou intensificando as atividades erosivas ao longo do Cenozóico (Terciário/Quaternário). A ocorrência de solos bem desenvolvidos e profundos, os Latossolos Vermelhos com ocorrência de horizontes concrecionários, sobre as Chapadas, sugerem a antiguidade dessas superfícies quase planas. $\mathrm{O}$ mesmo não ocorre com os solos nas áreas mais montanhosas onde prevalecem solos mais rasos, pedregosos e, portanto, mais recentes. Sintetizando, tem-se a seguinte sequência morfogenética:

1 - Formação do Cinturão Orogenético Brasília, no Proterozóico;

2 - Diversas, e não suficientemente identificáveis, fases erosivas desgastando as rochas dobradas e metamorfisadas, pertencentes à faixa dos dobramentos;

3 - Rebaixamento erosivo com aplanamento, formando as superfícies que hoje constituem as Chapadas, mas que no Pré-Terciário encontravam-se em níveis topográficos baixos;

4 - Ao longo do Cenozóico houve a reativação, com soerguimentos generalizados e basculamentos de blocos geológicos colocando as superfícies planas, das atuais chapadas, em nível altimétrico próximo do atual, ou seja, acima de $1200 \mathrm{~m}$, bem como as estruturas que sustentam as Serras Dourada, da Mesa, Traíras e outras;

5 - Concomitante a esse processo de reativação e soerguimento, pós Cretáceo, desenvolveram-se com maior vigor os processos erosivos que rebaixaram o relevo regional, gerando baixos planaltos e, sobretudo, as Depressões Intermontanas e do Tocantins e deixando como residual as atuais Chapadas e Serras;

6 - A presença das coberturas Terciário-Quaternário sobre as depressões, pouco espessas e ligeiramente dissecadas pela rede de drenagem atual, bem como os terraços dos grandes rios como Tocantins, sugerem que os entalhamentos da rede de drenagem ocorreram em função de reativações com pequenos soerguimentos mais recentes ao longo do Quaternário superior.

Nesta mesma perspectiva, os resultados de pesquisa de Valadão (2009), tratando da geodinâmica de superfícies de aplanamento e tectônica ativa nos relevos do Brasil Oriental, retomam as contribuições de Lester King (1956), elaborando uma análise morfogenética com resultados 
similares ao que se relatou nas pesquisas de Ross (1991a, 2001), para as faixas de dobramentos dos Cinturões Paraguai-Araguaia e de Brasília. Valadão (2009) identifica três níveis de superfícies de aplanamento tomando como referência a Superfície Sul-americana de King (1956) a partir da qual ocorreram pulsações tectônicas que permitiram retomadas erosivas com rebaixamentos significativos do relevo regional. Considera que os topos planos ou pelo menos aplanados e nivelados da Serra do Espinhaço, estendendo-se para o Quadrilátero Ferrífero, divisor de águas do rio São Francisco e das nascentes dos rios Doce, Jequitinhonha e outros, e das coberturas da Formação Urucuia (Cretáceo) definindo a Chapada do mesmo nome no divisor de águas das bacias do Tocantins-São Francisco, são testemunhos da Superfície Sul-americana. Estas superfícies podem ser correlacionadas às superfícies aplanadas das Chapadas de Brasília, dos Veadeiros (Distrito Federal e Goiás), da Serra da Canastra (MG) e com as superfícies aplanadas e/ou retilinizadas da Província Serrana de Mato Grosso, que tem partes recobertas pelos sedimentos do Grupo Parecis (Cretáceo).

Há, entretanto, discordância em relação às idades dessas superfícies, que tanto King como Valadão posicionaram entre o Cretáceo Inferior e o Terciário Médio, parecendo mais lógico que sejam do Cretáceo Inferior, neste caso podendo ser inclusive correlatas à Superfície Gondwana de King. Como são interpretações que consideram superfícies aplanadas e elevadas, de um lado, e de outro, depósitos de cobertura do Cretáceo, associando ambas com os processos tectônicos a partir do Jurássico, essas datações relativas oscilam entre o Cretáceo e o Terciário Médio, com significativo grau de imprecisão e incertezas. Os degraus morfológicos que Valadão (2009) identifica como Superfícies Sul-americana I e II, atribuindo idades a partir das atividades tectônicas do Mioceno e do Plioceno/Pleistoceno são convergentes com as interpretações das pulsações tectônicas do Neogeno (Terciário Superior e Quaternário). Estes níveis morfológicos são encontrados em várias áreas tanto na faixa de dobramentos do Atlântico como de Brasília e Paraguai-Araguaia e parecem de interpretação mais hegemônica.

\section{O relevo do Cráton Amazônico e das coberturas sedimentares}

Quando se voltam para os terrenos geologicamente mais antigos da América do Sul, com destaque para o Brasil e Venezuela, mais especificamente relacionados ao Cráton Amazônico, Ab'Saber (1972) e Ross (1990) registram que esta vasta superfície rebaixada tem altitudes que oscilam entre 100 e $300 \mathrm{~m}$, esculpidas em embasamento constituído por rochas metamórficas do Pré-Cambriano Médio (1,8 a 2,5 bilhões de anos). Essa superfície é a dominante do Cráton Amazônico desde o sul do Estado de Mato Grosso até a Venezuela e Guianas. Essa vasta superfície rebaixada que tanto caracteriza o Cráton Amazônico é contemporânea do Continente Gondwana e, portanto, sua origem é pré-Paleozóica, pois está recoberta parcialmente por sedimentos da Bacia Amazônica Oriental em franca discordância erosiva e estrutural. No território brasileiro, essa superfície foi denominada por Ab'Saber, em 1972, como Depressão Marginal Norte e Sul Amazônica em face da presença no eixo Leste-Oeste da Bacia Sedimentar da Amazônia Oriental. Esta bacia tem nas suas bordas norte e sul relevos cuestiformes, cujos topos estão entre 350/400m. O desnível entre os topos das bordas da bacia para a base da superfície, que está por volta dos 
100m de altitude, é de 200 a 300m. Essa superfície Gondwânica, passou então a ser tratada por Ab'Saber como uma "superfície de eversão", em função da exumação que teria ocorrido ao longo do Terciário-Quaternário e que colocou em descoberto um nivelamento pré-existente à formação da bacia paleo-mesozóica amazônica. Esse nível é brandamente inclinado tanto para norte como para sul, a partir do eixo do rio Amazonas. As características morfológicas dessa superfície, tanto a norte como ao sul da bacia amazônica, são dominantemente constituídas por colinas de topos convexos com vales encaixados e vertentes medianamente inclinadas.

Destaca-se por toda essa superfície baixa e colinosa, relevos pouco mais elevados, geralmente com altitudes entre 600 e $800 \mathrm{~m}$, mas que podem, em áreas restritas, ultrapassar os 1.000 metros. Esses relevos são sustentados por grande diversidade de litologias, como rochas ígneas da família dos granitos, com alguma presença de vulcânicas ácidas, como os riolitos, e coberturas residuais de plataforma, compostas por arenitos silicificados. Também estão presentes relevos residuais esculpidos em estruturas dobradas do Pré-Cambriano Médio representadas por cristas assimétricas de quartzitos, heranças de fases orogenéticas mais antigas que na evolução geológica levaram à formação do Cráton. Há ainda relevos cujos topos são mantidos por formações ferríferas e de manganês muito resistentes à erosão, que constituem depósitos supergênicos do PréCambriano e sustentam relevos residuais elevados, como ocorre com o complexo serrano de Carajás, no Pará, e de Urucum, em Mato Grosso do Sul.

Os arenitos silicificados também são extremamente resistentes ao desgaste e sustentam os topos aplainados/nivelados de planaltos com coberturas residuais de plataforma, a exemplo do que ocorre com as Serras da Providência e de Pacaás Novos, em Rondônia, do Cachimbo, de Caiabis, de Apiacás, de Santa Bárbara, de Tapirapé e de Cubencranquem, em Mato Grosso e Pará, e as Serras de Parima, de Pacaraima, em Roraima/Venezuela. Recobrindo parcialmente o Cráton Amazônico estão os pacotes das bacias sedimentares da Amazônia Oriental, cujo eixo hidrográfico é determinado pelo rio Amazonas e a bacia sedimentar do Parecis que se encontra no divisor de águas dos rios que vertem para o Amazonas, ao norte, e o rio Paraguai/Paraná, ao sul. Essas bacias têm o fecho da sedimentação nos arenitos do Cretáceo, com a diferença que as partes mais elevadas dos sedimentos do Cretáceo, na Bacia Amazônica, estão entre 350 e 400 m, enquanto no Planalto dos Parecis, oscilam entre 400 e 800 m. A Chapada dos Parecis, que corresponde à área mais elevada do Planalto dos Parecis está nivelada nos $800 \mathrm{~m}$, altitude semeIhante à borda da Bacia do Paraná, representada pela Chapada dos Guimarães, cujos topos também são mantidos pelos arenitos do Cretáceo. Essas bacias sedimentares estavam até o Cretáceo em posições topográficas baixas, o que permitia a recepção de sedimentos dominantemente arenosos de origem continental. O fato de estarem nos níveis altimétricos atuais indica que o cráton amazônico também foi alvo dos processos epirogênicos que se desdobraram ao longo do Cenozóico.

Ross (2014), reinterpretando a morfogênese da Chapada dos Guimarães (MT), posicionada na borda da Bacia do Paraná e praticamente contínua à Chapada dos Parecis, que se posiciona à noroeste, sintetiza que

[...] a Chapada dos Guimarães é produto da combinação de processos geotectônicos desencadeando movimentação crustal em razão da abertura do Atlântico, orogenia Andina e soerguimentos generalizados da plataforma sul americana a partir do Jura-cretáceo, e estendendo-se por todo o Cenozóico, somados aos arqueamentos dômicos ao longo dos grandes alinhamentos estruturais, como o que ocor- 
re ao longo da faixa de dobramentos Paraguai-Araguaia, denominado de Arco de São Vicente (ROSS, 2014, p. 195).

A faixa de dobramentos supra citado e o arqueamento de São Vicente estão entre as Chapadas dos Guimaraes, a sudeste, e Parecis, a noroeste, e como ambas são constituídas por rochas do Cretáceo (Grupos Bauru e Parecis) e também circundadas por escarpas seguidas de depressões e recobertas por camadas argilosas e ferruginosas, com solos profundos, os fatos alinhavados para interpretar a morfogênese da Chapada dos Guimaraes, também se aplicam à Chapada dos Parecis, com a diferença de que a primeira está na bacia do Paraná e a segunda está na borda do Cráton Amazônico. Tanto uma quanto a outra apresentam desníveis altimétricos entre 400 e $600 \mathrm{~m}$ entre os planos de topo e a base das depressões circundantes (Depressões Cuiabana, Alto Paraguai e Guaporé) ao sul. Parece evidente, que os soerguimentos que atuam no Arco de São Vicente se estendem mais para o oeste soerguendo de forma mais acentuada a extremidade sul do Cráton Amazônico e junto com ele a bacia sedimentar do Parecis (Chapada do Parecis). Estes fatos permitiram Ross (2014) considerar que estas chapadas e as depressões que as circundam, tanto ao sul quanto ao norte e oeste, foram geradas ao longo de mais de 60 Ma e não como suponha Ab'Saber (1972), que considerava como sendo decorrentes dos processos desnudacionais do Plio-Pleistoceno, ou seja, do rebaixamento erosivo produzido por três ou quatro milhões de anos.

No contexto das megaestruturas da América do Sul, a Plataforma da Patagônia também se apresenta preferencialmente como terras baixas, à semelhança do Cráton Amazônico, mas na perspectiva geomorfológica é bastante distinta. Essa Plataforma com parte das rochas mais antigas datadas do Pré-Cambriano Superior, acredita-se ser também parte residual do continente Gondwana. Sua configuração resulta do amalgaçamento de dois maciços cristalinos denominados de Somun Cura, ao norte, e Deseado, ao sul. Esses maciços se compõem de grande complexidade de rochas metamórficas e intrusivas da família dos granitos e vulcânicas ácidas, como os riolitos, associados ao vulcanismo do Jura-Triássico, e os basaltos, do Terciário inferior (Paleogeno).

Recobrem parcialmente essas litologias mais antigas, sedimentos do Cretáceo e Terciário que sustentam relevos tabulares em forma de mesetas de bordas escarpadas e topos aplanados. Nos setores em que afloram as rochas ígneas e metamórficas, a morfologia é marcada por relevos em morros e vertentes escarpadas, configurando uma intensa rugosidade topográfica. Ao contrário do território brasileiro, onde grande parte das coberturas do Cretáceo sobre rochas antigas foram removidas, prevalecendo quase que exclusivamente sobre as bacias sedimentares Paleomesozóicas, no baixo Planalto da Patagônia, essas coberturas se mantêm mais extensivamente, indicando ao mesmo tempo em que, embora essa plataforma esteja na borda da Cordilheira Andina, os soerguimentos epirogenéticos foram mais modestos, embora mais significantes na parte oeste da unidade em face da maior influência Andina.

As morfoestruturas, que sustentam os Planaltos e Chapadas das Bacias Sedimentares do Paraná, do Parnaíba, da Amazônia Oriental e do Parecis, têm em comum o fato de estarem em posições altimétricas mais elevadas do que no momento que foram geradas e por constituírem-se por sedimentos de arenitos de origem continental datados do Cretáceo. Com exceção da bacia do Parecis, cujos depósitos são exclusivamente do Cretáceo, as demais têm em suas formações geológicas sedimentos de várias origens (marinhos, continentais, glaciais), com idades que vão desde o Paleozóico (Devoniano, Siluriano, Carbonífero, Permiano) chegando ao Mesozóico, com 
sedimentos eólicos de ambientes áridos (Triássico), vulcânicas ácidas e básicas (TriássicoJurássico) e depósitos continentais em setores mais embaciados, dominantemente de arenitos (Cretáceo). O que desperta a atenção são de fato os soerguimentos, arqueamentos e sinéclises que estas bacias sofreram em todas suas extensões, mas principalmente em suas bordas. Essa epirogênese é considerada como Pós-Cretácea pelo fato de ter colocado os arenitos desta idade em posições altimétricas muito variadas, mas que chegam a 800/850m na Chapada dos Parecis, a 900/1000m nas bordas mais proeminentes da bacia do Paraná, como na Chapada dos Guimaraes, no Planalto Residual de Franca e de São Carlos-Botucatu, em São Paulo, e acima de 900m na Chapada do Ibiapaba, no Ceará-Piauí, na bacia do Parnaíba, ou em altitudes mais modestas nas bordas norte e sul da bacia da Amazônia Oriental, onde atinge no máximo 400m, no Planalto da Amazônia Oriental.

As bordas desses Planaltos e Chapadas são delimitadas por escarpas cujos processos erosivos Pós-Cretáceos, ou seja, Cenozóicos, foram induzidos pela tectônica que ao promover a epirogenia gerou falhamentos, a partir dos quais as atividades erosivas passaram a atuar. Ladeira e Santos (2006), estudando o relevo e os paleossolos na Formação Itaqueri, denominado por Ross e Moroz (1997) de Planalto Residual de São Carlos-Botucatu, em São Paulo, posicionada na borda leste da bacia do Paraná, no reverso da Cuesta de São Pedro, concluíram que a área foi afetada por complexa evolução geomorfológica durante o Cenozóico. No Paleoceno, a área foi afetada por subsidência seguida da formação de uma bacia sedimentar composta por leques aluviais em ambiente de clima semiárido, seguido por fase mais úmida, gerando vertentes em degraus. Desenvolveram-se solos sob condições de boa drenagem e também em condições lacustres no topo do Planalto. Por último, a área sofreu nova subsidência seguida por ressecamento climático e desenvolvimento de outro sistema de leques aluviais. Após este evento o clima voltou a ser quente e úmido e desenvolveu espesso pacote de perfil laterítico, no Neogeno. Durante o Neogeno (Terciário superior), houve nova atividade tectônica formando o atual planalto com evidente inversão de relevo, produto da ação combinada de processos neotectônicos e da erosão diferencial.

Esse conjunto de processos tectônicos e erosivos certamente não ocorreu de forma brusca e única, mas ao longo de mais de 60 milhões de anos (Cenozóico) e de modo concomitante, ou seja, ao mesmo tempo em que se processavam os esforços e a atuação tectônica, as erosões se instalaram e evoluíram na direção de promover Planaltos e Chapadas, nas bordas das bacias, e um amplo e generalizado rebaixamento morfológico, no entorno dessas bacias, na faixa de contato entre os sedimentos paleo-mesozóicos e as rochas que compõem as estruturas do cristalino. $\mathrm{O}$ rebaixamento erosivo da superfície foi, portanto, acompanhado e induzido pelas fases ou pulsos de soerguimentos/arqueamentos de origem tectônica.

As análises geomorfológicas, apresentadas por diversos autores, sinalizam na direção de que a abertura dessas superfícies rebaixadas, que deram origem às Depressões Periféricas e Marginais (AB'SABER, 1949/1972) que circundam parcialmente as grandes bacias sedimentares, foi esculpida por fases de maiores ou menores atividades tectônicas acompanhadas de maior ou menor vigor erosivo, em condições climáticas mais secas ou outras mais úmidas e quentes. Assim, essas depressões circundantes às bacias sedimentares (periféricas e marginais) são produtos da combinação entre os processos tectônicos Cenozóicos, com soerguimentos e falhamentos, e de processos erosivos promovidos por diferentes condições climáticas. Há um certo consenso 
de que os soerguimentos se deram de forma mais ou menos intermitente, ou seja, ainda que as atividades tectônicas nunca cessem, há momentos de maior ou menor intensidade. Essas variações de intensidades têm sido interpretadas como pulsações ou pulsos tectônicos e isto pode ter correlação com os momentos de maior ou menor atividade dos processos dos dobramentos andinos, onde se observam pelo menos três fases de orogenia pretéritas do Cretáceo Superior ao Cenozóico e uma atividade tectônica atual com soerguimentos dos depósitos quaternários costeiros do Pacifico.

\section{A neotectônica na interpretação do relevo}

Fato que também é praticamente consensual entre os mais diversos autores é que os processos geradores das formas atuais só podem ser melhor entendidos a partir do divisor temporal que é o Cretáceo. É também o Cretáceo, o grande "divisor das águas", ou seja, é ao longo do Terciário que as grandes bacias hidrográficas do continente sul-americano se redefinem e tomam sentido dominantemente para o Atlântico. Como se pode observar, as grandes bacias hidrográficas da América do Sul drenam para o Atlântico, numa indicação clara da barreira tectônica que a cordiIheira Andina exerce sobre essa drenagem. Como as águas são fluidas e têm seus fluxos comandados pela gravidade, os caminhos dos rios sul-americanos têm basicamente os grandes divisores de águas na cordilheira Andina, no extremo oeste, e nas faixas de dobramentos do Proterozóico, posicionados entre os Crátons Amazônico e do São Francisco e reativados pelos arqueamentos/soerguimentos do Cretáceo/Terciário, no centro e leste do Brasil.

Não é, portanto, mero acaso que a maior parte dos soerguimentos/arqueamentos identificados no território brasileiro estejam vinculados a setores dos Cinturões Orogenéticos antigos. Assim se dá com os arqueamentos no Rio Grande do Sul-Uruguai, no arco de Ponta Grossa, na flexura de Goiânia, no arco de São Vicente (MT), no arqueamento do Nordeste Oriental (Borborema), no Espinhaço/Quadrilátero Ferrífero, entre outros. Essas áreas têm em sua gênese o histórico da atividade tectônica, desde o momento que surgiram como estruturas dobradas, metamorfizadas e magmatizadas. É de se esperar, portanto, que essas áreas se constituam nas mais sensíveis aos eventos geotectônicos mais recentes em função de sua história genética. Há, entretanto, muitos "segredos" geomorfogenéticos a serem desvendados no futuro. O que é aceito pela grande maioria dos pesquisadores interessados no tema, é que apesar de todas as dificuldades, é mais fácil identificar na paisagem marcas dos processos tectônicos e erosivos nos depósitos de sedimentos do Terciário Superior ao Quaternário (Plioceno, Pleistoceno, Holoceno).

Ross $(1987,1991)$, em trabalhos acerca da geotectônica e morfogênese da Província Serrana (MT), identificou nos depósitos da Formação Pantanal, na alta bacia do rio Paraguai e tributários (Rios Sepotuba e Pari), espessos pacotes sedimentares do Pleistoceno, com camadas de seixos rolados do Arenito Silicificado (Formação Raizama) recobertos por areias e argilas, com horizontes concrecionários descontínuos. O entalhamento dos vales principais e a dissecação do relevo com drenagem hierarquizada foram interpretados pelo autor como decorrentes de neotectônica, considerando a possibilidade de pulsações tectônicas de pequena envergadura, porém de 
efeitos significativos, entalhando os vales e formando os terraços fluviais.

A despeito da evolução das técnicas de mapeamento, de identificação e datação dos materiais, grande parte das interpretações continua sendo dependente das formações geológicas do Terciário Médio ao Quaternário, tomando-se como ponto de referência o evento da deriva dos continentes/abertura do Atlântico/separação do continente Gondwana. Gontijo (1999), em estudo acerca da morfotectônica do Médio Paraíba do Sul, fez valiosa revisão sintética sobre as informações geotectônicas do Brasil de sudeste. Entre as informações está a interpretação de Saadi (1993) que correlaciona os pulsos andinos identificados por Frutos (1981) e os eventos neotectônicos brasileiros, que ocorreriam na seguinte sequência:

- No Eoceno-Oligoceno (Incaic II) - quando se inicia o período neotectônico do rift da Serra do Mar e formação das bacias do Quadrilátero Ferrífero e sedimentação do Barreiras;

- No Plioceno (Quetchuan II) - ocorrido em escala global, responsável pelo rift de São João Del Rei e deposição das formações Guararapes, Solimões, formação de bacias lacustres isoladas e pelo soerguimento de várias áreas;

- No Pleistoceno Inferior a Médio (Yarmouthian) - ocorrência da emersão de partes do litoral com basculamento das camadas do Grupo Barreiras e soerguimento generalizado da Plataforma sul-americana.

No contexto dessa revisão de Gontijo (1999), outras informações podem ser destacadas como a ocorrência de falhamentos normais e reversos em conglomerados fluviais no interior do Estado de São Paulo (Riccomini, 1991); a afirmação de Hasui et al. (1998), sobre a configuração da paisagem do sudeste brasileiro como decorrente da separação do continente sul-americano, no Mesozóico, resultando em soerguimento regional do Mesozóico ao Paleogeno (Terciário Inferior), seguido de grandes desnivelamentos de blocos através de falhas responsáveis pela individualização das serras ancestrais do Mar e Mantiqueira e pela geração dos grábens Terciários, havendo no Neogeno-Quaternário (Plioceno e Pleistoceno) a compartimentação da região em grandes domínios morfológicos. Gontijo (1999), também ressalta que Salamuni (1998), identificou dois episódios tectônicos superpostos gerando descontinuidades na bacia de Curitiba: o primeiro associado às rupturas NE e ENE e NW, relacionados ao arco de Ponta Grossa; o segundo, neotectônico, relacionado às descontinuidades $\mathrm{NE}$, que afetam tanto o embasamento quanto os sedimentos cenozóicos.

As atividades tectônicas que atuaram no continente sul-americano, a partir do Jurássico e ao longo do Cretáceo e Cenozóico, com prevalência no Terciário, foram responsáveis pelos processos geradores dos rifts marcados por falhamentos transcorrentes, escarpamentos, geração de grábens/horsts e formação nessas depressões tectônicas de bacias sedimentares sintectônicas, ou seja, de formação concomitante à atividade tectônica. Estes processos tanto ocorreram nas terras emersas como na plataforma continental e talude, sobretudo na faixa atlântica desde o litoral do Rio Grande do Sul ao Nordeste Oriental. São exemplos representativos as bacias sedimentares nas terras emersas ou, das também denominadas, bacias continentais trafogenéticas, as bacias Cenozóicas de São Paulo, Taubaté, Rezende, Curitiba, Pariquera-Açu, Volta Redonda, Guanabara, Itaboraí, geradas, conforme Ricomini, (1989), a partir do Oligoceno-Mioceno.

Nas áreas submersas, esse mecanismo tectônico de geração de sistema de rifts, possibili- 
tou concomitante aos processos tectônicos, a formação de várias bacias preenchidas por sedimentos marinhos e continentais. De acordo com Gontijo (1999), essas bacias sintectônicas são as de Pelotas, Santos, Campos Espirito Santo, Bahia-Sul e Sergipe-Alagoas, conforme registradas por Chang et al. (1988). Essas bacias têm processos deposicionais desde o Cretáceo estendendo-se para o Terciário/Quaternário, com diferentes fases de sedimentação marinha em condições ora de mares rasos, ora mais profundas, em função dos processos de subsidências geradas ao longo do Cretáceo e, sobretudo, no Terciário.

Desde a publicação de Ricomini (1989), conforme afirma Gontijo (1999), tem-se informações claramente demonstradas, que essas atividades tectogenéticas continuam ativas após a formação dos depósitos sedimentares, quando esse autor identificou deformações nos sedimentos das bacias continentais de Rezende e que se proliferam nos depósitos das bacias vizinhas, conforme se pode com certa frequência observar em cortes sobre as colinas da bacia de Taubaté, por ocasião da execução de obras civis de infraestrutura viária.

As deformações observadas nesses sedimentos podem ser atribuídas às pulsações tectônicas atuantes no Terciário Superior e Quaternário, sendo correlacionáveis com a presença de uma área de hot spot representado pela ocorrência de uma pluma no manto, que exerce pressão sob a listosfera, promovendo vulcanismo e atividades sísmicas e consequentes deformações mais recentes. Essa pressão do hotspot, no Atlântico, na direção do litoral sul e sudeste do Brasil, com correspondência no litoral da Namíbia e Angola, foi preconizada por Cox (1989), e incorporada às interpretações sobre a morfotectônica por Gontijo (1999), que também explica porque a área continental dessa região foi a mais soerguida e provavelmente a mais afetada pela tectônica mesocenozóico no território brasileiro.

As pesquisas de Antônio Magalhaes Junior, nos anos de 1993/1994 e 2008/2009, e de seus colaboradores, com destaque para o estudo sobre os Níveis de Terraços Fluviais e Depósitos Sedimentares Correlativos no Alto Vale do Rio das Velhas no Quadrilátero Ferrífero-MG (SANTOS et al., 2009), mostram que os depósitos fluviais da bacia do rio das Velhas, relacionados ao período Quaternário mais recente (Pleistoceno Superior/Holoceno) são compostos de estratos desde seixos, na camada basal, passando por finos de diferentes calibres. Entretanto o que é mais significativo, na perspectiva genética, é o fato de se encontrarem três níveis de terraços, cuja espessura total oscila entre 35 e $50 \mathrm{~m}$, a partir da lâmina d'água. Esse entalhamento já fora interpretado por Magalhães Junior e Saadi (1994) como sendo efeitos da tectônica neo-cenozóica, o que é absolutamente convergente no contexto das análises mais atuais sobre o papel da neotectônica, sobretudo considerando o fato de que tais resultados são encontrados nos setores mais elevados do relevo brasileiro. .

Nessa direção, Bertolini (2015), em pesquisa sobre a alta bacia do rio Piranga (MG), destaca que nessa bacia observa-se uma clara reincisão da rede hidrográfica atribuída a uma captura de drenagem das proximidades. Entretanto, destaca que "[...] próximo à foz do Córrego Maria Luísa ocorre um terraço fluvial, composto por duas linhas de seixos rolados, posicionados 20 metros acima do atual leito do rio Piranga" (BERTOLINI, 2015, p. 107). Complementa com outros indicadores de uma provável tectônica recente, ao sinalizar que "[...] a presença de horizontes subsuperficiais com características de gleização pretérita, encontrados nem sempre nas proximidades dos atuais eixos de drenagem, [...] seria preciso pensar em mudanças do nível freático induzidas por variações climáticas ou uma tectônica ascendente [...]" (BERTOLINI, 2015, p. 166). Mais adi- 
ante considera "[...] acreditamos que de fato um alçamento neotectônico desses horizontes gleizados é plausível com o contexto ambiental atual" (Idem).

Ao pesquisar a variabilidade morfológica em níveis de base do rio uéchua -MG no quadrilátero ferrífero, Lana e Castro (2010) concluíram que a reativação neocenozóica de estruturas dos terraços deste rio, de idades sugeridas como do Pleistoceno e Holoceno é uma continuidade temporal desses processos no Eoceno/Mioceno já indicados por outros autores que estudaram estes fatos na região. Hartwig e Riccomini (2010), ao fazerem análise morfotectônica da serra dos uéchu-Sudeste do Brasil enfatizam que em uma primeira fase evento tectônico no Eoceno gerou por distenção de direção NW-SE o rifth continental do sudeste brasileiro, gerando blocos alongados e escalonados abatidos para Sudeste. Em uma segunda fase, houve a deformação de antiga superfície de aplanamento com nivelamento das serra dos uéchu a $2.000 \mathrm{~m}$, e numa terceira fase, o cisalhamento dextral, decorrente do evento tectônico seguinte de idade pleistocênicaHolocênica, envolveria a retomada dos processos erosivos com desenvolvimento da drenagem ao longo dos lineamentos NW-SE realçados por facetas trapezoidais. Etcheberhere et al. (2004), identificou deformações neotectônicas no vale do rio do Peixe-oeste paulista, onde os terraços fluviais pleistocênicos gerados pelo entalhamento do talvegue deste rio, expõe pacote de sedimentos de mais de $40 \mathrm{~m}$.

Na bacia do rio Piracicaba, na Depressão Periférica Paulista, Pinheiro e Queiroz Neto (2015, p. 610), admitem expressamente que "Os impactos da neotectônica na área estudada são a formação e degradação de parte dos terraços fluviais dos afluentes da margem direita do Piracicaba", e conclui mais a frente que "[...] a atual configuração geomorfológica da área da Serra de São Pedro e do baixo rio Piracicaba é fortemente condicionada pela tectônica recente".

Os resultados apresentados por Ribeiro et al. (2011) sobre a evolução tectônica e desnudacional da Serra do Mar, mais precisamente nos planaltos da alta bacia do rio Paraíba do Sul, em área conhecida como Planalto de Paraitinga, aplicando técnica de datação através de análises de traços de fissão E U-TH/HE em apatitas concluiu que, houve no Cretáceo Superior ao Paleoceno forte alçamento tectônico e a partir do qual se instalam ciclos erosivos. Sugere também, baseado nessa análise, que teria ocorrido outra provável atuação tectônica no Eoceno-Oligoceno. Estes resultados são convergentes com outras informações já apresentadas aqui.

Esse emaranhado de contribuições, ainda que pareçam complexas, indicam que todo o planalto brasileiro encontra-se sob influência dos processos tectônicos mais recentes, que afetam os níveis de base e a partir destes processa-se a retomada erosiva em cada uma das bacias desencadeando as capturas de drenagem e dissecação generalizada do relevo.

A partir destas claras evidências dos efeitos tectogenéticos mais recentes (Terciário e Quaternário), é possível considerar que o continente sul-americano tem, nos tempos atuais, dois grandes eixos de arqueamentos, sendo um NE-SW na faixa atlântica e outro no interior do continente. O eixo do interior tem extensão desde a Cordilheira Andina Oriental, onde está o divisor de águas entre o rio Pilcomayo (que drena para o rio Paraguai e os rios Beni e Mamoré que drenam para o rio Madeira/Amazonas), projetando-se na direção da faixa dos dobramentos do Cinturão Orogenético Paraguai-Araguaia (arco de São Vicente), atingindo a bacia do rio Araguaia. O eixo da fachada atlântica tem sua extensão desde a faixa litorânea do Estado do Rio Grande do Sul (borda da bacia do Paraná), projetando-se para o sudeste e centro-norte, na direção das faixas de dobra- 
mentos nos Cinturões Orogenéticos de Brasília e do Atlântico (Espinhaço/Quadrilátero Ferrífero). Parece-nos que esta interpretação torna-se mais consistente, quando se analisam os resultados parciais apresentados por Assumpção et al. (2015), sobre os dados de 2013 e 2014 gerados pela Rede Sismográfica Brasileira. O pequeno mapa síntese que ilustra a referida publicação, mostra claramente alguns eixos ou áreas onde a concentração de abalos sísmicos é maior no território brasileiro, sendo bastante evidente a concentração na faixa atlântica, com destaque a região sudeste e a faixa que adentra para o centro norte do país acompanhando os Cinturões Orogenéticos do Atlântico, Brasília e Paraguai-Araguaia. Nessa interpretação, pode-se conjeturar sob a influência da subducção da placa de Nazca (Peru, Chile, Bolívia) atuando no soerguimento da faixa orogênica Paraguai-Araguaia, borda sul do Cráton Amazônico e borda norte e noroeste da Bacia do Paraná, enquanto o Hot Spot do Atlântico sul, interfere na faixa centro-leste, sudeste e sul do Cinturão do Atlântico e borda leste e sul da Bacia do Paraná. Estas influências de grande magnitude geotectônica de certo modo individualizam e respondem pelo comportamento tectônico na América do Sul em duas grandes partes. A parte norte delimitada pelo Cráton Amazônico e representada nos Andes a partir da inflexão que esta cordilheira apresenta para oeste na altura do norte do Chile, Peru e Bolívia e a outra parte que compreende o cone sul e o centro leste do Brasil.

\section{A orogenia andina e os seus reflexos no relevo brasileiro}

A Cordilheira Andina e a Depressão Central Sul-americana são partes de um mesmo contexto geotectônico. A Depressão Central Sul-americana se estende desde a Venezuela, onde está instalada a bacia hidrográfica do rio Orenoco, abrangendo o alto Solimões, na Amazônia Ocidental, a alta bacia dos rios Beni-Mamoré-Guaporé, as bacias do rio Paraguai e do baixo rio Paraná-Prata. Constitui-se por relevo de altitudes modestas, cujos valores mais altos estão a 250 m, no interflúvio das bacias dos rios Beni-Mamoré e Paraguai, em território boliviano. Em sua extensão nortesul, pelo centro do continente sul americano, há áreas constituídas por Planícies e Pantanais, como ocorre com parte da alta a média bacia do rio Orenoco, onde estão as Savanas do mesmo nome, ou na alta bacia dos rios Beni-Mamoré, onde estão os Chacos, com campos, e os Pantanais, como os do Guaporé, no Brasil, ou ainda as Planícies e Chacos/Pantanais, do rio Paraguai, onde se inclui o Pantanal de Mato Grosso e os Chacos da Bolívia e Paraguai.

Entretanto, alguns setores dessa vasta depressão apresentam-se com relevos ligeiramente mais elevados, onde a rede de drenagem encontra-se hierarquizada e promove a dissecação, desgastando os sedimentos terciários das formações argilosas, como as da bacia sedimentar do Solimões, no Brasil-Peru-Colômbia, e outras duas menores, nas proximidades da foz do rio Orenoco, na Venezuela, e no divisor de águas Mamoré-Paraguai, na Bolívia. Embora essa vasta depressão seja modelada em superfície por sedimentos terciários e quaternários, sua estrutura vincula-se diretamente com a formação da Cordilheira Andina. É, portanto, uma condição estrutural pré-andina, compondo-se por um segmento baixo e aplanado que separa as estruturas antigas, no centro-leste do continente, das estruturas dobradas e vulcânicas, da porção oeste. O que está sob a capa sedimentar terciário-quaternário são falhas, dobras e fossas tectônicas, cujos arranjos estruturais são típicos de ambientes orogenéticos ativos. 
Nesse contexto, o Pantanal de Mato Grosso ou do Alto Paraguai corresponde a um prolongamento para leste dessa vasta depressão central. Esse Pantanal, cujas altitudes estão entre 100 e $150 \mathrm{~m}$, compõe-se de um pacote sedimentar terciário-quaternário, cujas espessuras maiores atingem pouco mais de $400 \mathrm{~m}$. Os sedimentos inconsolidados de superfície, que sustentam os relevos baixos, são decorrentes de processos deposicionais em sistemas de leques aluviais que, ao longo do Pleistoceno e Holoceno, ao mesmo tempo se acumulavam, nos transbordamentos fluviais das inundações, se desgastavam e se remanejavam. A paisagem dominante do Pantanal é uma combinação de resíduos de diques fluviais de constituição arenosa, representando as Cordilheiras e espaços pouco mais baixos e planos, inundáveis periodicamente, sobretudo por águas pluviais que se acumulam no período chuvoso. Fonseca (2015), em pesquisa sobre o Pantanal de Poconé (MT), descreve e caracteriza essas formas de relevo, suas gêneses e idades, onde o mecanismo dominante são os leques aluviais, em que aparecem as Cordilheiras recobertas de vegetação arbustiva, os campos inundáveis absolutamente planos e os campos inundáveis com murunduns. A diversidade dos materiais e das morfologias é marcada pelas diferenças de solos e, consequentemente, pelas coberturas vegetais.

Os Pantanais, que compõem o complexo pantaneiro de Mato Grosso ou do Alto Paraguai, são uma combinação de processos tectônicos vinculados à orogenia Andina, com reflexos nos soerguimentos da faixa de dobramentos Paraguai-Araguaia e da borda oeste da bacia do Paraná, onde gerou e reativou um feixe de falhamentos. Esse conjunto de falhas afetou tanto os sedimentos da bacia do Paraná como as estruturas rígidas do embasamento, representado pelas litologias dos Grupos Cuiabá e Paraguai. Os prováveis degraus tectônicos existentes estão encobertos pelos sedimentos da bacia do Pantanal, cujo pacote se compõe pelos sedimentos erodidos das bordas da bacia do Paraná, ao longo do Terciário e Quaternário. As fisionomias dominantes em cada um dos Pantanais, que compõem o complexo Pantanal do Alto Paraguai, estão comandadas por amplos leques aluviais de rios como o Taquari, o São Lourenço, o Cuiabá, o Negro e o Paraguai.

A Cordilheira dos Andes, que se estende de norte a sul em paralelo e entre a Depressão Central, a leste, e o Oceano Pacifico, a oeste, é tipicamente uma decorrência dos processos da deriva dos continentes e, portanto, das atividades sísmicas associadas à movimentação das placas litosféricas da América do Sul (continente sul americano) e as placas de Nazca e do Pacífico que estão sob as águas do oceano. A submersão ou subducção das placas de Nazca e do Pacifico (sul), sob a placa Sul americana, é o mecanismo que explica a dominância dos processos geotectônicos que ocorrem em todo o continente e fornece as pistas para a interpretação da evolução do relevo no território brasileiro. Zalan (2004), ao sintetizar dados sobre a orogenia andina produzidos por diversos autores, indica que o processo de formação da Cordilheira Andina se deu por fases de dobramentos que se iniciam no Cretáceo Médio (96/106 milhões de anos), denominada de fase Mochica, pré-Andina. A essa fase inicial de dobramentos acrescentam-se outras, como a fase Peruana Cretáceo, um pouco mais recente, da ordem de 83 a 87 milhões de anos; a fase Cordilheira Ocidental, também do Cretáceo Superior, com tempo da ordem de 65 a 74 milhões de anos. No Cenozóico, outras duas fases orogenéticas são identificadas: a fase Incaica do Cenozóico-Eoceno, com 33 a 53 milhões de anos, e a fase uéchua-Cenozóico-Mioceno/Plioceno, entre 1,7 a 23 milhões de anos.

Essas fases de orogenia se encaixam em alguns fatos morfoestruturais muito significantes tanto para o entendimento da compartimentação do relevo da Cordilheira Andina, como para os 
seus reflexos no Planalto Brasileiro. A fase Mochica, do Cretáceo Médio, articula-se com a existência da Cordilheira Andina Oriental e com o denominado Altiplano Boliviano, com topos posicionados acima de 4000 metros de altitude. As fases Cordilheira Ocidental, do Cretáceo Superior, e a Incaica, do Cenozóico Médio (Eoceno), associam-se a toda extensão do eixo central da Cordilheira Andina, desde o extremo sul do Chile à Colômbia e à Venezuela, cujas altitudes oscilam em 2600m para estruturas sedimentares dobradas ou com extensas áreas soerguidas e niveladas, constituindo amplos patamares aplanados em determinados setores da cordilheira.

Para as faixas de vulcanismo, as altitudes chegam a mais de $4000 \mathrm{~m}$ e acompanham linearmente todo o centro (de norte a sul) da cordilheira. A fase uéchua do Terciário Médio ao Superior (Mioceno/Plioceno) refere-se à última fase de dobramentos que atingem a Cordilheira da Costa, que é preferencialmente composta por sedimentos terciários dobrados e secundariamente derrames vulcânicos. Esse relevo ocorre de forma descontinua acompanhando o litoral chileno, não sendo claramente identificada no litoral do Peru, reaparecendo de forma também descontínua nos litorais da Colômbia e da Venezuela (vertente do Pacífico). A cordilheira da Costa, ou Costeira, tem altitudes que oscilam em torno dos $1.500 \mathrm{~m}$ e é acompanhada, no interior, de forma também descontínua, por depressões paralelas, alongadas e dominantemente planas, com altitudes, em geral, $500 \mathrm{~m}$ mais baixas. Observa-se, entretanto, que no Chile essas depressões internas, que possivelmente representam grandes vales sinclinais, perdem altitude de norte para o sul. Enquanto no extremo norte do Chile, um segmento dessas depressões, na região da cidade de Calama, tem altitudes por volta dos $1.400 \mathrm{~m}$. Mais para o sul, onde se encontra a metrópole de Santiago, as altitudes estão ao redor dos 700/800 m, e, no extremo sul do país, uma dessas depressões encontra-se afogada pelas águas oceânicas, oferecendo um litoral extremamente recortado e entremeado por serras, morros, vulcões e mares interiores.

No contexto geral, os setores mais elevados regionalmente correspondem à faixa do sul do Peru e do norte do Chile, em direção leste para o território da Bolívia, onde prevalecem as terras mais altas da Cordilheira Andina Oriental. É nessa faixa que se encontram, sobre os Andes, as nascentes dos rios Pilcomayo, que drena para o rio Paraguai, e dos rios Beni e Mamoré, que drenam para o rio Madeira e, portanto, para a bacia Amazônica. A sutil divisão das águas dessas grandes bacias vincula-se certamente às influências da subducção da placa de Nazca, gerando arqueamento nos Andes com reflexo sobre a faixa de dobramentos antigos do ciclo brasiliano, representado no centro do continente pelo cinturão orogenético Paraguai-Araguaia que tangencia o sul e o leste do Cráton Amazônico.

As fases da orogenia Andina, conforme Zaidan (2004), são correlacionáveis às fases de soerguimentos preconizados por Fernando Flávio Marques de Almeida (1967/1969), que indica para o Cretáceo Inferior, no contexto da fase de orogenia Mochica, o início do soerguimento do Sudeste e Nordeste Oriental do Brasil. No Cretáceo Superior uma nova fase ou pulso de soerguimento para estas regiões do território brasileiro, que se estende até o Cenozóico inferior (Eoceno), correspondendo às fases Cordilheira Ocidental e Incaica, indicando que na fase uéchua, no Cenozóico Superior (Mioceno/Plioceno), ocorreu mais uma fase de soerguimento com registros datados no Planalto da Borborema, no Nordeste Oriental do Brasil. Estabelece, entretanto, correlação entre a orogenia Andina-fase Incaica ao longo do Cenozóico médio (Mioceno/Eoceno) com o rifteamento e formação das bacias sedimentares de Taubaté, Rezende, Itaboraí, Guanabara, Volta Redonda, São Paulo, Curitiba, entre outras. 
No entanto, não faz nenhuma referência à possível relação entre os processos de soerguimentos no território brasileiro e as atividades orogênicas na cordilheira andina ao longo do Pleistoceno e Holoceno (Quaternário), enfatizando que nos últimos 1,7 milhões de anos observa-se uma certa calmaria tectônica no continente sul americano.

Neste sentido, o relevo correspondente aos níveis de terraços marinhos e tabuleiros, encontrados descontinuamente tanto no litoral do Pacifico, como no litoral norte/nordeste e leste do Brasil, correspondendo aos sedimentos da Formação Barreiras, tida como depositada no Terciário Superior (Mioceno/Plioceno), só poderia ser explicado pelas oscilações dos níveis marinhos. Entretanto a existência de espessos pacotes sedimentares compondo terraços fluviais com 20 a 50 $\mathrm{m}$ de espessura com evidentes reentalhamentos de vales, acompanhados de recuos de cabeceiras, capturas fluviais e generalizada e intensa dissecação do modelado no interior do continente junto aos planaltos e montanhas, não podem ser explicados por movimentos dos níveis marinhos ou simplesmente por mudanças climáticas seco-úmido. Considera-se aqui, que estas evidências, reforçam a interpretação de que há atividade tectônica atual (pleistoceno/holoceno) influenciando na modelagem das formas menores, como já enfatizado neste trabalho, quando se tratou da influência da neotectônica na configuração do relevo.

\section{Proposição de classificação do relevo para a América do Sul}

Esse grande volume de informações geológicas e geomorfológicas, produzidas por inúmeros autores, somadas às consultas ao Mapa Geológico da América do Sul e o uso sistemático das imagens de satélite disponíveis no Google Earth e de radar SRTM produzidos pela NASA, foram fundamentais para compor este texto sobre a morfogênese regional da América do Sul e culminar com uma nova proposta de representação das unidades de relevo do continente sul-americano, com destaque para o Brasil. Para isto, seguiu-se a proposta metodológica embasada nos conceitos de morfoestrutura e morfoescultura, preconizados pelos geomorfólogos russo-soviéticos I. Guerasimov e J.A. Mecerjakov, conforme Mecerjakov (1968).

A primeira classificação geral do relevo da América do Sul foi elaborada por George Berry, publicada no livro Geomorphology de O. D. Von Engeln, em 1942. Nessa publicação, as unidades geomorfológicas da América do Sul foram divididas em cinco grupos (de $A$ a $E$ ) representadas em mapa (Figura 1). Esses grupos foram denominados de: A-1- Coastal Plains; A-2-Piemont Plains; A-4- Fluvial, Lacustrine and Deltaic Plains; A-6- Glacial Plains; B-8- Interior Plateaus; B-9- Open Basins with Centripetal Dips; B-10- Lava Flow Plains and Plateaus; B-11-Volcanic Cones; D-15Fold Mountains, Simple Folds; e, E-17- Ancient Igneous Masses.

Esta foi sem dúvida a primeira tentativa de se entender a distribuição e as características do relevo sul-americano. $\mathrm{Na}$ atualidade, quando se dispõe de enorme quantidade de publicações, sobretudo da geologia e geomorfologia do Brasil e do continente como um todo, associado às tecnologias disponíveis, é possível apresentar-se uma nova versão sobre o tema, com a preocupação de tornar mais claras as relações existentes entre as formas e as estruturas do relevo brasileiro, frente aos arranjos estruturais e morfológicos de todo o continente. 


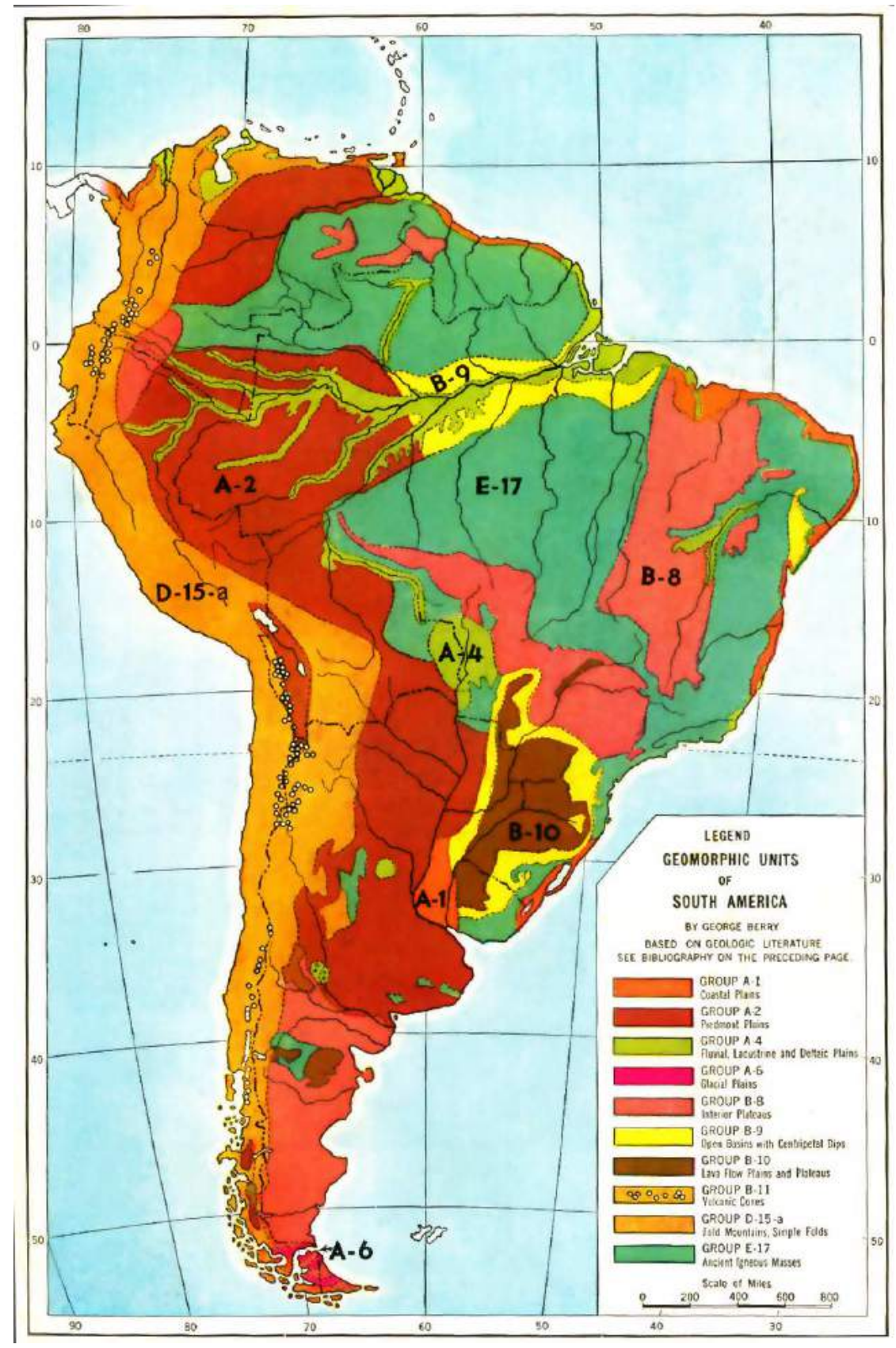

Figura 1. Relevo da América do Sul segundo G. Berry (ENGELN, 1942).

Dessa forma, as denominações das unidades que ora se propõem, considerando o relevo brasileiro no contexto da América do Sul, diferem ligeiramente das denominações e arranjos apresentados em outros trabalhos publicados anteriormente, em função da análise ser agora feita no contexto sul-americano. Procurou-se seguir a divisão do relevo a partir das macroestruturas geológicas que definem as mega unidades das morfologias do Brasil e do restante do continente. Os nomes destas também passaram por ligeiras modificações, pois, tanto as bases geológicas como o relevo, não coincidem com os limites político-administrativos das nações que compõem a divisão geopolítica do continente. 
Segue-se, portanto, a divisão do primeiro e grande táxon, as morfoestruturas do Cráton Amazônico, dos Cinturões Orogênicos Antigos, da Plataforma da Patagônia, das Bacias Sedimentares Paleo-mesozóicas, dos Cinturões Meso-cenozóicos, das Bacias Sedimentares Cenozóicas. O segundo táxon corresponde à divisão morfoescultural dos planaltos, depressões, montanhas e planícies que pertencem a cada uma dessas megaestruturas.

\section{Conclusões e reflexões: a tectônica e os rebaixamentos erosivos}

Nesta síntese não se discutiram as questões relativas aos efeitos climáticos e paleoclimáticos no contexto dos processos esculturais do relevo brasileiro. Há entendimento entre os pesquisadores da geomorfologia brasileira, que houve variações e mesmo mudanças climáticas, sobretudo no Quaternário, com climas oscilando entre os áridos e semiáridos, de períodos mais frios, seguidos por períodos mais quentes e úmidos, e que certamente isso interferiu na morfogênese e pedogênese de forma determinante. Optou-se, entretanto, tratar esses processos genericamente como erosivos de diferentes fases, face às dificuldades de comprovação, por falta de depósitos correlativos que se configurem como testemunhos confiáveis, para os tempos que vão além do PliocenoPleistoceno. Grande parte dos denominados depósitos correlativos das fases erosivas de pediplanação, considerados na literatura como testemunhos de climas áridos ou semiáridos, são constituídos por materiais fragmentários rudáceos quartzosos de morfologias angulosas e dimensões heterométricas. Esses materiais quartzosos quase sempre procedem de veios de quartzo contidos em rochas metamórficas como micaxistos, filitos, migmatitos entre outros. Como os seixos em forma de fragmentos de quartzo (sílica) são pouco solúveis, acabam por manter-se acumulados em forma de camadas descontínuas (stone lines) no manto de alteração dessas rochas e dominantemente acumulam-se residualmente entre o horizonte $C$ (alterito) da rocha matriz e o horizonte $\mathrm{B}$, representado pela cobertura pedológica. Pode-se afirmar assim que essas pseudo-camadas ou lentes de fragmentos de quartzos, que aparecem sobre as vertentes em processos desnudacionais, acompanham grosseiramente a morfologia das vertentes.

Os depósitos rudáceos, constituídos basicamente por fragmentos angulosos de quartzo e de quartzitos, que recobrem descontinuamente topos de superfícies elevadas e aplanadas, denominadas de Superfícies dos Campos, Superfícies das Cristas Médias, Superfície Japi, entre outras, também têm sido tomadas na literatura geomorfológica como testemunhos de fases climáticas secas. Acredita-se, entretanto, que tanto essas coberturas rudáceas, como os Neossolos Litólicos, frequentes nessas áreas montanhosas, são produtos de processos geoquímicos atuando diferenciadamente sobre os minerais das rochas que dão suporte a esses relevos. São relevos elevados e montanhosos, já apresentados e discutidos, que em função da maior resistência litológica, onde prevalecem rochas ricas em sílica (quartzos), sendo mais resistentes aos processos de intemperismo, gerando ao invés de solos, fragmentos rochosos. Os demais minerais agregados à composição rochosa, como os da família dos feldspatos (sódicos, potássicos) e da família das micas, sobretudo biotitas, se intemperizam mais rapidamente e os minerais solubilizados são transportados pelas águas superficiais e subterrâneas, bem como os materiais sólidos finos (argilas) que são carreados pelas águas de superfície. Ficam como resíduos, os materiais grosseiros, blocos 


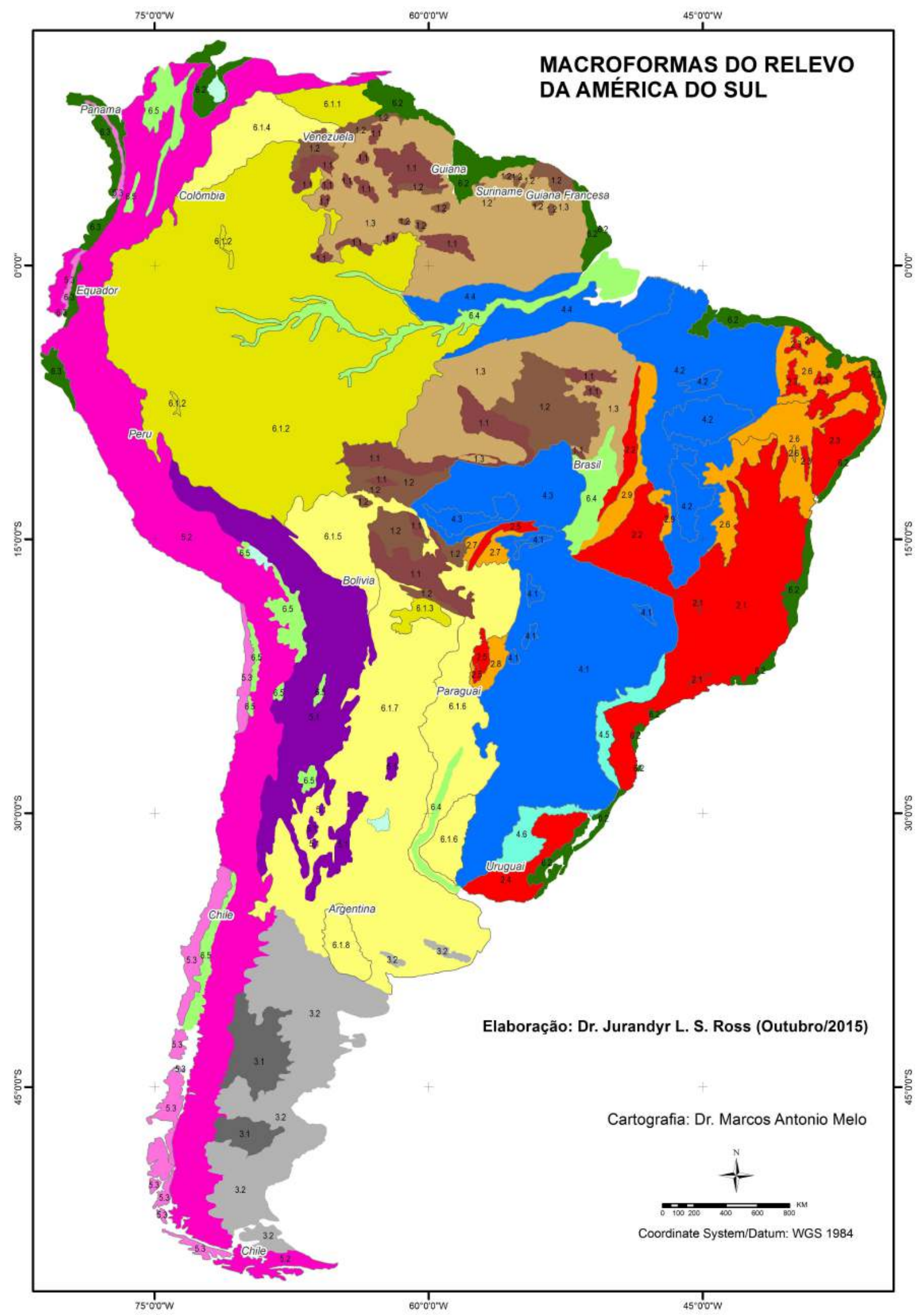

Figura 2. Mapa do relevo da América do Sul: nova compartimentação (legenda a seguir). 


\section{Macroformas do Relevo da América do Sul}

\section{Morfoestruturas do Cráton Amazônico}

1.1, Planaltos Residuais em Coberturas de Plataformas - Norte e Sul Amazônicos

1.2, Planaltos em Estruturas Igneas e Metamórficas - Norte e Sul Amazônicos

1.3, Depressões Marginais e Interplanálticas - Norte e Sul Amazônicos

\section{Morfoestruturas dos Cinturőes Orogenéticos Antigos}

2.1, Planaltos e Serras do Atlântico Leste-Sudeste

2.2, Planaltos e Serras de Goiás-Minas

2.3, Planaltos do Nordeste Oriental

2.4, Planaltos Uruguaio-Sulriograndense

2.5, Planaltos e Serras do Alto Paraguai/Bodoquena

2.6, Depressões Sertaneja e do São Francisco

2.7, Depressões Cuiabana e do Alto Paraguai

2.8, Depressões do Miranda-Bodoquena

2.9, Depressões do Tocantins

\section{Morfoestruturas da Plataforma da Patagônia}

3.1, Planaltos em Estruturas Vulcano-Sedimentares

3.2, Planaltos em Coberturas Sedimentares Meso-Cenozóicas

Morfoestruturas em Bacias Sedimentares Paleo-mesozóicas

4.1, Planaltos e Chapadas da Bacia do Paraná

4.2, Planaltos e Chapadas da Bacia do Parnaíba

4.3, Planaltos e Chapadas da Bacia do Parecis

4.4, Planaltos e Tabuleiros da Bacia da Amazônica Oriental

4.5, Depressão Periférica da Borda Leste da Bacia do Paraná

4.6, Depressão Periférica Central Gaúcha-Uruguaia

Morfoestruturas em Cinturões Orogenéticos Meso-cenozóicos

5.1, Cordilheira dos Andes Oriental

5.2, Cordilheira dos Andes Centro-Ocidental

5.3, Cordilheira dos Andes Costeira

Morfoestruturas das Bacias Sedimentares Cenozóicas

6.1 Depressão Central Sulamericana

6.1.1, Tabuleiros e Colinas da Bacia do Orenoco

6.1.2, Tabuleiros e Colinas da Bacia do Solimões

6.1.3, Tabuleiros e Colinas do Alto Paraguai

6.1.4, Planícies e Pantanais da Bacia do Orenoco

6.1.5, Planícies e Pantanais das Bacias Beni-Mamoré (Chaco)

6.1.6, Planícies e Pantanais das Bacias Paraguai-Paraná (Chaco)

6.1.7, Planícies e Colinas das Bacias Paraguai-Paraná-Prata

6.1.8, Planícies e Campos de Dunas Fixas das Bacias do Salado-Colorado

6.2, Tabuleiros e Planícies Costeiras do Atlântico

6.3, Tabuleiros e Planícies Costeiras do Pacífico

6.4 , Planícies Fluviais Interiores

6.5, Planícies e Colinas em Vales Sinclinais Intermontanos 
seixos heterométricos e angulosos de quartzo e quartzitos, compondo pavimentos superficiais e paleopavimentos subsuperficiais, que não obrigatoriamente têm a ver com climas secos.

Em fundos de vales planos, sobretudo em terraços fluviais, ocorrem depósitos de seixos rolados de mesma composição (quartzos e quartzitos). Nesses casos pode-se considerar que os alúvios, com camadas de material grosseiro sobrepostos ou sotapostos às camadas de areias e argilas, podem de fato representar momentos de maior torrencialidade e, portanto, de maior capacidade de transporte de materiais de maior calibre, evidenciando momentos de chuvas torrenciais em condições possivelmente de climas mais secos. A revisão dos conhecimentos sobre os significados das linhas de pedras, stone lines, ou linha de seixos, apresentada por Hiruma (2007), ajuda a entender os fatos acima referidos.

Vitte (1998), ao estudar os processos morfogenéticos da bacia do Ribeira do Iguape, pertencente à faixa do Cinturão do Atlântico, vem ao encontro com o que Ross (1987, 1991, 1998), conclui analisando a evolução do relevo nos Cinturões Orogenéticos. Pode-se perceber que as variações altimétricas e as configurações morfológicas estão associadas a uma complexidade de processos que envolvem a tectônica Pré-Cambriana, a reativação tectônica do Meso-Cenozóico, os arranjos lito-estruturais dos bandeamentos, os antigos níveis de erosão desmontados pela tectônica, as antigas superfícies de erosão exumadas pelos processos erosivos Cenozóicos e também os rebaixamentos morfológicos desiguais decorrentes das atividades geoquímicas das águas. Ainda nessa direção, Ross e Moroz (1997) e Ross (1998), constataram que os diferentes níveis morfológicos/topográficos encontrados nos planaltos do leste paulista, nos terrenos do Cinturão do Atlântico, estão relacionados a uma complexidade de processos morfogenéticos, que se manifestam no espaço e no tempo e que envolvem atividades tectônicas de diferentes tempos e gêneses, como dobramentos, metamorfismos, magmatismos, falhamentos antigos, reativação de falhas no Cenozóico, juntamente com evidências de antigas superfícies de erosão.

Nessa região, Ross (1998) chama a atenção para os diferentes níveis morfológicos/topográficos que se observam entre as estruturas rochosas representadas pelas massas de granitos (batólitos), como as das Serras do Itapeti, da Cantareira, de Itaqui, de São Francisco, de São Roque, de Paranapiacaba, do Caparaó, da Bocaina, dos Órgãos, entre várias outras, que estão com seus topos em níveis altimétricos entre 850/900m a 1000/1400m, ao lado dos relevos esculpidos nas massas rochosas de quartzitos, como o Pico do Jaraguá, a Serra do Japi, as Serra de Voturuna, da Canastra, do Espinhaço, a Chapada Diamantina, cujos topos encontram-se entre 1100/1200 metros ou mais e que são fortemente resistentes ao desgaste, testemunhando as superfícies Pré-Cenozóicas, possivelmente do Cretáceo. Ao redor desses relevos proeminentes, encontra-se vasta superfície cujos topos se nivelam ao redor dos $800 \mathrm{~m}$ de altitude, preferencialmente esculpidos em rochas metamórficas, sobretudo migmatitos e gnaisses, entremeados por extensas faixas de micaxistos e filitos que por sua vez frequentemente estão em posições topograficamente mais rebaixadas.

Esses fatos levaram Ross (1998) a considerar para os planaltos da faixa do Cinturão do Atlântico, no Estado de São Paulo, que:

[...] a evolução do relevo da região tem, nos processos tectônicos mesocenozóicos, importante papel como desencadeador de vigorosos processos esculturais, tanto nas escarpas das Serras do Mar e Mantiqueira, quanto nas superfícies de topos dos planaltos [...]; 


\section{$[\ldots]$}

[...] esses processos esculturais já se faziam presentes no Pré-Cenozóico e criaram significativas diferenças altimétricas em função das variações litológicas e de arranjos estruturais destas, não sendo obrigatoriamente superfícies de erosão distintas, e sim rebaixamentos desiguais de superfícies do relevo por processos dominantemente geoquímicos decorrentes de umidade e temperaturas mais elevadas e transporte mecânicos por ação fluvial.

\section{$[\ldots]$}

[...] os depósitos em bacias sedimentares Cenozóicos de finos (argilas) sendo relativamente pouco expressivos em extensão e volume frente a extensividade das áreas com relevos fortemente dissecados, sugere predominância de processos de desgaste (erosão e transporte) por dissolução química dos minerais primários, permanecendo in situ apenas os "resíduos" dos processos geoquímicos", as argilas e areias.

$[\ldots]$

[...] a presença de relevos mais elevados mantidos por rochas ígneas maciças (granitos e sienitos) e rochas metamórficas (quartzitos) circundados por relevos mais baixos esculpidos em rochas metamórficas que apresentam maior densidade de linhas de fraqueza, também sugerem a prevalência de processos geoquímicos de desgaste erosivo, consubstanciado em rebaixamento geoquímico (ROSS, 1998, p. 691).

Considera-se que o processo de meteorização das rochas constituídas por minerais primários e as transformações em minerais secundários que compõem a cobertura pedológica e os depósitos Cenozóicos, é um significativo processo escultural, onde os minerais dissolvidos são transportados para as águas oceânicas, restando sobre os continentes os resíduos arenosos de quartzo e mais restritos ainda os materiais finos (argilas).

Com a preocupação de encontrar respostas sobre a velocidade de rebaixamento do relevo brasileiro, com destaque para a região do Quadrilátero Ferrífero, especificamente a alta bacia do Rio das Velhas, Salgado et al. (2007) apresentaram resultado de pesquisa usando o marcador do isótopo cosmogênico Berilo $\left({ }^{1} \mathrm{Be}\right)$. Trabalhos anteriores do próprio autor indicaram que na região há três patamares de resistência aos processos fortemente relacionados ao rebaixamento com velocidade desigual vinculados às tipologias de famílias de rochas, onde as mais frágeis são as carbonáticas, as de resistência intermediária, xistos, filitos e granito-gnaisses, e as mais resistentes, cangas, itabiritos e quartzitos. Com exceção dos itabiritos e cangas, abundantes no Quadrilátero Ferrífero, à semelhança da Serra dos Carajás, no Pará, e Maciço do Urucum, em Mato Grosso do Sul, que são depósitos supergênicos de alta resistência ao desgaste e sustentam os topos aplanados/nivelados destas serras, as demais se encaixam nas características gerais do que ocorre no relevo em todo o território nacional, onde prevalecem as rochas metamórficas e ígneas que sustentam os relevos elevados dos cinturões orogenéticos e do Cráton Amazônico.

Essas interpretações são deduzidas a partir de mapeamentos geológicos e geomorfológicos regionais. O uso dos marcadores, nesse caso o Berilo 10, é sem dúvida um avanço tecnológico importante para as pesquisas geomorfológicas. Assim, os resultados da pesquisa de Salgado et al. (2007) indicam taxas de rebaixamento, amostrados em sedimentos, da ordem de 1,71 a $2,58 \mathrm{~m} / \mathrm{Ma}$; taxas entre 7,95 e 11,82 m/Ma, para xistos e filitos; e de 12,92m/Ma, para granitos/gnaisses. Permitiu também verificar a ampliação altimétrica em 10m/Ma entre as terras altas e baixas da alta bacia do Rio das Velhas, em Minas Gerais. Nas considerações finais, afirmam que 
foi possível comprovar sobre a evolução do relevo da bacia do rio das Velhas que

1) As terras altas são extremamente resistentes frente ao rebaixamento vertical do relevo (downwearing), mas são frágeis diante da retração lateral das escarpas (backwearing).

2) Ao longo do último 1,5 Ma ocorreu uma ampliação da altitude das escarpas que separam as terras altas das terras médias e baixas.

3) Graças à dissecação do relevo regional, as terras baixas ganharam área em detrimento das terras médias ao longo do Quaternário.

4) As terras altas da alta Bacia do Rio das Velhas praticamente não sofreram processos de dissecação e nem tiveram significativa diminuição de área ao longo do Quaternário (SALGADO et al., 2007, p. 8).

Neste contexto, a pesquisa de Vervloet (2015), na bacia do rio Benevente, no sul do Estado do Espirito Santo, que drena estruturas rochosas do Cinturão do Atlântico, identificou claramente que rochas com maior presença de minerais ácidos e, portanto, mais quartzosos, sustentam morros e escarpas, enquanto que nas áreas que concentram rochas com mais presença de minerais como anfibólios, piroxênios, biotitas, as formas do relevo são mais baixas, do tipo colinas com topos convexizados e solos mais profundos, associando estes fatos ao rebaixamento geoquímico.

Em publicação recente, Vilella et al. (2015), apresenta resultado de pesquisa na borda leste da bacia do Paraná, nos relevos da Depressão Periférica Paulista, no contato com as rochas do embasamento cristalino do Planalto Atlântico, constatando que devido aos processos atuação da hidrolise mais avançada nas formas de relevo mais aplainadas, ocasionadas pela ocorrência de gibbsita e argilo-minerais como a caulinita, é possível notar a existência de processos de erosão geoquímica na formação da superfície. Continua explicando que os processos de lixiviação e dissolução de minerais é concomitante às superfícies mais aplainadas, indicando rebaixamento da topografia.

Assim sendo, ainda que se tenham parcos testemunhos de que nos tempos passados houve climas mais secos que contribuíram para os processos esculturais do relevo regional, são as atividades geoquímicas dos ambientes úmidos, e preferencialmente quentes, que estabelecem a marca definitiva nos processos morfoesculturais nas formas de relevo em serras, morros e colinas. Por outro lado, são os processos morfotectônicos e arranjos morfoestruturais, juntamente com as diferenças de resistências aos desgastes das diferentes famílias de rochas, que estabelecem os parâmetros para a compartimentação das unidades de relevo e o entendimento de sua respectiva morfogênese.

Diante do que foi exposto, fica evidente que não se pode estabelecer uma relação direta e absoluta entre as superfícies de aplanamento, os diferentes níveis morfológicos ou topográficos e as idades das formas, bem como apenas considerar os aspectos da tectônica meso-cenozóica como causa das variações altimétricas das morfologias.

Pode-se, entretanto, estabelecer algumas generalizações de âmbito regional, admitindo-se que os níveis aplanados, ou pelo menos retilinizados, dos topos das faixas de dobramentos (Cinturões), sejam testemunhos de fases erosivas do Cretáceo ou anteriores, como as extensas superfícies niveladas e baixas que estão esculpidas sobre os Crátons Amazônico e do São Francisco, e que as depressões interplanálticas e superfícies embutidas nas bordas das grandes bacias sedimentares, sejam de idade mais recentes (Terciário e Quaternário). 
Do mesmo modo, a partir das contribuições aqui registradas e indicadas nas referências, nos atrevemos a afirmar que os níveis morfológicos ou topográficos, locais e regionais, associamse às diversas origens e gêneses, mas sempre contemplando a tectônica cenozóica, que promove soerguimentos/arqueamentos/basculamentos, e os processos erosivos concomitantes, que atuam nos rebaixamentos e deposições.

Sob essa perspectiva, pode-se destacar de forma sintética que são observáveis:

1 - Extensos níveis planos ou de topos retilíneos nivelados, em posição de cimeira, que testemunham superfícies antigas de erosão, seja do Cretáceo ou do Pré-Cretáceo, com destaque os setores mais elevados dos cinturões orogenéticos antigos. Esses níveis, geralmente acima de $1200 m$, são em grande parte mantidos por quartzitos ou arenitos silicificados. São exemplos as Serras do Espinhaço (MG), da Canastra (MG), Dourada e da Mesa (GO), Província Serrana (MT), Chapada Diamantina (/BA), entre inúmeras outras. Também ocorrem em níveis pouco mais elevados com litologias diversas e com configuração de Chapadas, como a dos Veadeiros (GO) e de Brasília (DF), decorrentes dos deslocamentos tectônicos do Cenozóico (Terciário Médio-Eoceno-Oligoceno);

2 - Topos retilinizados, posicionados em dois ou mais níveis altimétricos, diferenciados por blocos basculados por efeito da tectônica antiga reativada no meso-cenozóico, gerando horsts e grábens, como ocorre nas Serras da Mantiqueira, do Mar e da Bocaina (SP/MG/RJ), dos Orgãos, entre outras;

3 - Topos retilinizados ou nivelados em níveis altimétricos diferenciados, esculpidos em estruturas cristalinas e/ou cristalofilianas, por efeito da meteorização e rebaixamento geoquímico desigual, como ocorre no Planalto Atlântico, entre os morros e serras esculpidos em rochas metamórficas e ígneas de diferentes resistências ao desgaste. São exemplos as serras esculpidas em forma de cristas em quartzitos, como Japi, Voturuna, as serras em batólitos graníticos, como a do Caparaó, da Cantareira, e os morros pouco mais baixos esculpidos em migmatitos, micaxistos e filitos;

4 - Níveis de Patamares Estruturais definindo superfícies planas a levemente inclinadas nos interiores e bordas de bacias sedimentares, como ocorre no Planalto dos Parecis, Planaltos das Bacias do Paraná e Parnaíba, resultantes da combinação da epirogenia/tectônica mesocenozóica e os processos erosivos concomitantes no tempo e no espaço;

5 - Níveis em patamares estruturais escalonados definindo superfícies planas ou em rampas de pouca declividade, condicionadas pelos planos de acamamento de diversas fases de derrames de lavas vulcânicas básicas e ácidas comuns na bacia do Paraná, decorrentes da combinação dos processos vulcânicos ocorridos principalmente no Jurássico, o soerguimento por epirogenia do conjunto da bacia sedimentar e os processos erosivos concomitantes atuando com maior ou menor intensidade em função das diferenças de resistência de desgaste das rochas e de seus planos de acamamento;

6 - Superfícies aplanadas antigas, sepultadas por depósitos sedimentares e posteriormente exumadas, posicionadas nas margens de bacias sedimentares denominadas de superfícies de eversão ou de depressões marginais dominantemente sobre o Cráton Amazônico nas Depressões Marginais e Interplanálticas Norte e Sul Amazônicas, no Cinturão Para- 
guai/Araguaia nas Depressões Cuiabana e do Alto Paraguai, no Cinturão de Brasilia, na Depressão do Tocantins, e no Cinturão do Atlantico e Cráton do São Francisco, no contexto das Depressões Sertaneja e do São Francisco, que remontam aos processos erosivos herdados do Continente Gondwana;

7 - Superfícies rebaixadas e aplanadas por processos erosivos generalizados, posicionadas entre bordas de bacias sedimentares e maciços antigos, correspondentes às depressões periféricas, como a Depressão Periférica da Borda Leste da Bacia do Paraná e a Depressão Central Gaúcha-Uruguaia, resultantes da atividade conjunta da epirogenia/tectônica e erosão ao longo do Cenozóico;

8 - Superfícies de topos planos, posicionadas em reverso de escarpa das bordas das grandes bacias sedimentares, denominadas de Chapadas e esculpidas sobre os arenitos do Cretáceo como ocorre com as Chapadas dos Guimarães, Parecis (MT), Urucuia (BA), Mangabeiras (PI), entre outras;

9 - Níveis diferenciados de topos de ocorrência local ou regional, associados a corpos intrusivos (batólitos) ou vulcânicos/corpos graníticos, sienitos, riolitos, andesitos mais resistentes ao desgaste erosivo e constituindo morros e serras que se destacam na paisagem, como Maciço do Itatiaia, do Caparaó, Cantareira, São Francisco, Itapeti, Itaqui entre outras;

10 - Níveis diferenciados associados a fases de deposição e de erosão, alojados nas depressões tectônicas (Horst/Gráben), como os Vales do Ribeira (SP), do Paraíba (SP/RJ), do Alto Tietê (SP), Itaboraí (RJ) entre outras, relacionadas à tectônica Cenozóica (Eoceno/Plioceno);

11 - Pequenos níveis diferenciados associados a fases de deposição/erosão Quaternárias de ambientes de sedimentação fluvial, marinha ou lacustre, correspondendo aos terraços fluviais e marinhos e às planícies fluviais e marinhas, com cronologia relacionada ao Pleistoceno e Holoceno.

Na dinâmica constante manifesta na América do Sul através de oposições de processos endogenéticos, promovendo soerguimentos epirogênese/tectônica, e de processos exogenéticos, causando rebaixamentos erosivos, ambos nos 65 milhões de anos do Cenozóico, pode-se no campo meramente especulativo imaginar que as taxas médias de soerguimentos chegariam até a 15 metros a cada um milhão de anos e, em contrapartida, os desgastes erosivos seriam menores, por volta de seis a sete metros a cada um milhão de anos.

Dentro do que foi aqui apresentado, considera-se, que ainda não se tem solução definitiva sobre a compartimentação e a morfogênese do relevo brasileiro, mas seguindo os princípios que norteiam o processo de pesquisa, ou seja, a procura constante por novas indagações e respostas, este trabalho tem a intenção de gerar uma síntese aproximativa, no sentido de estabelecer uma maior correlação entre a compartimentação e a origem/evolução do conjunto do relevo do continente sul americano. 
Referências

AB'SABER, A.N. Regiões de Circundesnudação Pós-Cretáceos no Planalto Brasileiro. Boletim Paulista de Geografia v.1, p. 1-21, 1949.

Posição das Superfícies Aplainadas no Planalto Brasileiro. Geomorfologia v.20, p. 1022, 1960.

. Um conceito de Geomorfologia a Serviço das Pesquisas sobre o Quaternário. Geomorfologia v.18, 15 p., 1969.

. Participação das Depressões e Superfícies Aplainadas na Compartimentação do Planalto Brasileiro. Geomorfologia v.28, 20 p., 1962.

. Megageomorfologia do Território Brasileiro. In: CUNHA, S.B. \& GUERRA, A.J.T. (Org.), Geomorfologia do Brasil. Rio de Janeiro: Bertrand Brasil, 1998, p. 71-106.

ALMEIDA, F.F.M. Os Fundamentos Geológicos do Relevo Paulista. DNPM/DGM, Boletim. Rio de Janeiro, 1964, p. 1-60.

Origem e evolução da Plataforma Brasileira. DNPM/DGM, Boletim. Rio de Janeiro, 1967, p. 22-45.

ASSUMPÇÃO, M; BARBOSA, J.R; BIANCHI, M; DROUET, S.; ROCHA, M.P.; FERREIRA, J.M. Sismos Regionais Detectados pela Rede Sismográfica Brasileira-RSBR em 2013-2014. In: XV SIMPÓSIO NACIONAL DE ESTUDOS TECTÔNICOS. Anais... Vitória, 2015.

BERTOLINI, W.J. A Alta Bacia do rio Piranga-MG: Estudo geomorfológico a Propósito da Condição do Equilíbrio do Relevo. Tese de Doutoramento. São Paulo: FFLCH-USP, 2015.

BIGARELLA, J.J.; MOUSINHO, M.R.; SILVA, J.X. Contribuição ao estudo da Formação PariqueraAçu. Boletim Paranaense de Geografia v.16/17, p. 17-41, 1965.

CASTRO, P.T.; LANA, C.E. Variabilidade Morfológica em Níveis de Base do Rio Maracujá, Quadrilátero Ferrífero: Influências Litológicas, Estruturais e de Reativações Cenozóicas. Revista Brasileira de Geociências v.11, n.1, p. 21-30, 2010.

COX, R.T. The Role of Mantle Plumes in the Development of Continental Drainage Patterns. Nature v.342, p. 21-28, 1989.

DE MARTONNE, E. Problemas Morfológicos do Brasil Tropical Atlântico. Revista Brasileira de Geografia v.4, p. 4-25, 1943.

ENGELN, O.P. Geomorphic Units. New York: Macmillan, 1942.

ETCHEBEHERE, M.L.; SAAD, A.R.; FULFARO, V.J.; PERINOTTO, J.A. Detection of Neotectonic Deformations along the Rio do Peixe Valley, Western São Paulo State, Brazil, based on the distribution of late Quaternary allounets. Revista Brasileira de Geociências v.6, p. 109-114, 2004.

FONSECA, G.P.S. Formas de Relevo e os Materiais de Superfície do Pantanal de PoconéMT. Tese de doutoramento. São Paulo: FFLCH-USP, 2015. 
FRUTOS, J. Andean Tectonic as a Consequence of Sea-floor spreading. Tectonophycs v.72, p. 21-32, 1981.

GONTIJO, A.H.F. Morfotectônica do Médio Vale do Rio Paraiba do Sul: região da Serra da Bocaina Estados de SP-RJ. Tese de doutoramento. Rio Claro: Instituto de Geociências e Ciências Exatas-UNESP, 1999.

HARTWIG, M.E.; RICCOMINI, C. Análise Morfotectônica da Região da Serra dos Órgãos, Sudeste do Brasil. Revista Brasileira de Geomorfologia v.11, n.1, p. 11-20, 2010.

HIRUMA, S.T. Revisão dos Conhecimentos sobre o Significado das Linhas de Seixos. Revista do Instituto Geológico de São Paulo v.27/28, p. 53-64, 2007.

KING, L.C. A Geomorfologia do Brasil Oriental. Revista Brasileira de Geografia v.18, p. 1-120, 1956.

LADEIRA, F.S.B.; SANTOS, M. Tectonic and Cenozoic Paleosols in Itaqueri's Hill (São PauloBrazil): Implications for the Long Term Geomorphological Evolution. Geomorphology (N.F Suppl.) v.145, p. 37-62, 2006.

MENDES, L.D.; FERNANDES, N.F.; GONTIJO, A.H.F. Morfotectônica da Bacia Hidrográfica do Rio Bonito - Petrópolis, RJ. Revista Brasileira de Geociências v.8, n.1, p. 63-77, 2007.

MESCERJAKOV, J.P. Les Concepts de Morphostruture et de Morphosculture: un nouvel instrument de l'analyse géomorphologique. Annales de Géographie v.423, p. 539-552, 1968.

PINHEIRO, M.R.; QUEIROZ NETO, J.P. Neotectônica e Evolução do Relevo da Região da Serra de São Pedro e do Baixo Rio Piracicaba/Sudeste do Brasil. Revista Brasileira de Geomorfologia v.16, n.4, p. 594-613, 2015.

RICCOMINI, C. O Rift Continental do Sudeste do Brasil. Tese doutoramento. São Paulo: Instituto de Geociências-USP, 1989.

RIBEIRO, M.C.S; HACKSPACHER, P.C.; RIBEIRO, L.F.B; STOCKLID; HADLER NETO, C. Evolução Tectônica e Denudacional da Serra do Mar-Sudeste do Brasil no Limite entre o Cretáceo Superior e Paleoceno, Utilizando Análise de Traços de Fissão E U-TH/HE em Apatitas. Revista Brasileira de Geomorfologia v.12 (n. especial), p. 3-14, 2011.

ROSS, J.L.S. Estudo e cartografia geomorfológica da Província Serrana, MT. Tese de doutoramento. São Paulo: FFLCH/USP, 1987.

. Relevo Brasileiro: Uma nova proposta de classificação. Revista do Departamento de Geografia (USP) v.4, p. 25-39, 1990.

O Relevo Brasileiro, as Superfícies de aplainamento e os Níveis Morfológicos. Revista do Departamento de Geografia (USP) v.5, p. 7-24, 1991.

. O Contexto Geotectônico e a Morfogênese da Província Serrana de Mato Grosso. Revista I.G v.12, n.1/2, p. 21-37, 1991.

Superfícies de Erosão ou Erosão Química nos Processos de Esculturação dos Planaltos do Leste Paulista. Geosul v.1, n.1, p. 688-691, 1996.

. Geomorfologia e Geografia Aplicadas à Gestão Territorial: Teoria e Metodologia 
para o Planejamento Ambiental. Tese de Livre Docência. São Paulo: FFLCH/USP, 2001. $322 p$.

A Morfogênese da Bacia do Ribeira do Iguape e os sistemas ambientais. Revista GEOUSP v.12, p. 21-46, 2002.

. O Relevo Brasileiro nas Macroestruturas Antigas. Revista Continentes v.1, n.2, p. 8-27, 2013.

Chapada dos Guimarães: Borda da Bacia do Paraná. Revista do Departamento de Geografia (USP) v.28, p. 180-197, 2014.

ROSS, J.L.S.; MOROZ, I.C. Mapa Geomorfológico do Estado de São Paulo - escala 1:500.000. São Paulo: FFLCH-USP-IPT-FAPESP, 1997, 64p.

SAADI, A. Neotectônica da Plataforma Brasileira: esboço e interpretações preliminares. Revista Geonomos v.1, p. 1-15, 1993.

SALAMUNI, E. Tectônica da Bacia Sedimentar de Curitiba-PR. Tese de doutoramento. Rio Claro: Instituto de Geociencias-UNESP, 1998.

SALGADO, A.A.R; VARAJAO, C.A.C; COLIN, F. Estimativa das Taxas de Erosão das Terras Altas da Alta Bacia do Rio das Velhas no Quadrilátero Ferrífero: Implicações para Evolução do Relevo. Revista Brasileira de Geomorfologia v.8, n.2, p. 3-10, 2007.

SANTOS, G.B.; MAGALHAES Jr., A.; CHEREM, L.F.S. Níveis de Terraços Fluviais e Depósitos Sedimentares Correlativos no Alto Vale do rio das Velhas-Quadrilatero Ferrífero-MG. Revista Brasileira de Geomorfologia v.10, n.1, p. 73-84, 2009.

VALADÃO, R.G. Geodinâmica de Superfícies de Aplanamento, Desnudação Continental e Tectônica Ativa como Condicionantes da Megageomorfologia do Brasil. Revista Brasileira de Geomorfologia v.10, n.2, p. 77-90, 2009.

VERVLOET, R.J.H.M. Elementos de Geomorfologia Estrutural: Estudo Aplicado a Região Serrana do Espírito Santo. Vitória: Edição do Autor, 2015.

VILELLA, F.N.J.; ROSS, J.L.S.; MANFREDINI, S. Análise Geomorfológica na Borda Leste da Bacia do Paraná - Sudeste do Brasil. Revista Brasileira de Geomorfologia v.16, n.4, p. 669682, 2015.

VITTE, A.C. Etchplanação em Juquiá (SP) - Relações entre o Intemperismo químico e as mudanças climáticas no desenvolvimento das formas de relevo em margem cratônica passiva. Tese de doutoramento. São Paulo: FFLCH/USP, 1998. 276p.

ZALAN, P.V. Evolução Fanerozóica das Bacias Sedimentares Brasileiras. In: Geologia do Continente Sul-americano: Evolução da obra de F.F.M.de Almeida. São Paulo: Editora Beca, 2004, p. 595-613. 